\title{
Sicilya'da Hanefilik
}

\author{
Hanafism in Sicilia
}

\begin{abstract}
Abdullah ACARa
a Dr. Öğr. Üyesi, Necmettin Erbakan Üniversitesi Ahmet Keleşoğlu İlahiyat Fakültesi İslam Hukuku Ana Bilim Dalı e-Posta: abacar42@hotmail.com, http://orcid.org/0000-0001-5792-4712/
\end{abstract}

\begin{tabular}{cc}
\multicolumn{2}{c}{ Makale Bilgileri } \\
\hline Geliş Tarihi: & 30.04 .2019 \\
Kabul Tarihi: & 14.06 .2019 \\
Yayın Tarihi: & 26.06 .2019
\end{tabular}

\begin{abstract}
Özet
Günümüze kadar gelebilme başarısı gösteren mezhepler içerisinde ve Müslüman coğrafyada en fazla müntesibi bulunan ve Doğudan Batıya en çok tanınan mezhep Hanefì mezhebidir. Hanefì mezhebinin bu kadar taraftar bulmasinda İmam-ı A'zam'ın görüş ve düşünceleriyle mezhep anlayışının teşekkülündeki kurucu kişiliği, hocalarından aldiğı fikhî yorumları günün şartlarına göre doğru biçimde yorumlaması ve kıyasla birlikte istihsan metodunu icat etmesinin rolü büyüktür. Buna, Hanefiliğin resmi mezhep olarak kabul edilmesi, Ebu Hanife'nin öğrencilerinin mezhep fikhın tedvin etmeleri, nesilden nesile mezhep görüşlerini aktaracak bir öğrenci silsilesinin bulunması ve kanun koyma ihtiyacı gibi sebepler de ilave edilebilir.

Hz. Peygamber'in yeni Müslüman olan topluluklara gönderdiği muallim ve kadı uygulaması daha sonraki halifeler döneminde de aynen devam ettirilmeye çalışılmıştır. Müslümanların Doğu topraklarında başlayan ilk fetihleri ile bu topraklara İslam ahlakı ve adabını öğreten fakih şahıslar aracılığı ile Müslümanların ibadetleri ve günlük hayatlarını kuşatan fikıh ya da hukuk da götürülmüştür. Bu uygulama İslam'ın Batı'ya geçişteki ilk noktası olan Misır ve daha sonra yayılacağı Kuzey Afrika'da da aynen korunmuştur. Hz. Osman döneminden başlayarak Mısır'a gönderilen ve daha sonra adil halife Ömer b. Abdülaziz döneminde de devam ettirilen muallim ve fakih şahsiyetler gönderme uygulamaları, bu coğrafyanın öncelikle Müslümanlaşmasına, ardından da bu şahısların etrafinda oluşan şahsa dayalı müstakil mezheplerin oluşmasina vesile olmuştur.

Kûfe, Medine, Şam gibi merkezlerde hicri II. yüzyıldan itibaren başlayan mezheplerin oluşum süreci, Batıdaki coğrafyayı da etkilemiştir. Doğu'daki medreselerde eğitim alan birçok fakih, aldıkları bu eğitimi Batı'da yeni fethedilen topraklara nakletmişler, böylece mezhepleşme olgusu Doğu ile Batı'da aynı anda başlamiştır denilebilir. Bu dönemde, aralarında Hanefi mezhebinin kurucusu Ebu Hanife'nin ve ögrencilerinin de bulunduğu birçok müctehid imamın görüşleri bu coğrafyaya öğrenciler aracılı̆̆ girmeye başlamiştır.

Özellikle 750 yılında Emevilerden sonra iktidara gelen Abbasilerden itibaren Hanefiliğin resmi mezhep olarak devlet yönetiminde aktif rol yüklenmesiyle birlikte, öncelikle Doğuda Mâverâünnehir topraklarina uzanan Hanefi mezhebi, hemen hemen aynı zaman diliminde öncelikle Kuzeybatı Afrika'ya, oradan da Sicilya ve Endülüs topraklarına kadar yayılmıştır. Bu makalede, Hanefi mezhebinin Batı topraklarına geçişi, kâdîların bu mezhebin yayılmasındaki katkıları, bu kadılar arasında öncelikle Sicilya fatihi Esed b. Furat'in etkisi ve daha sonraki kadıların yaptıklari katkılar, adada Hanefiligin taraftar bulmasındaki sebepler ve etkisini kaybettiği yillar içeren kısa bir silsile takip edilecek ve mezhebin Sicilya'daki seyrinin tarihçesi ortaya çıkarılmaya çalışılacaktır.
\end{abstract}

Anahtar Kelimeler: İslam hukuku, Hanefïlik, Sicilya, Mezhep, Fıkıh Coğrafyası.

\section{Giriş}

Hanefi mezhebinin Doğudan Batıya çok geniş topraklara yayılması ve bunun nedenleri dikkatleri çekmektedir. Günümüzde taraftarı bulunan dört mezhebin imamları arasında en yaşlısı, en tecrübelisi ve silsile bakımından en kuvvetlisine sahip olan, belki de bu sebeple 
İmam-1 A'zam lakabıyla meşhur Ebu Hanife'ye ait fikhî yorumlar, aslında öncelikle öğrencileriyle müzakere edilir, bir karara bağlanarak icraya konurdu. Böylesine dinamik bir yapıya sahip olmasının verdiği güçle, ondan sonra gelen talebeleri, $z-h-b$ kelimesinin anlamlarından birisini olussturan altın madenine sahip çıarcasına onun görüşlerine/zehabına sahip çıkmışlar, bu altın değerindeki ictihatlar da alıcı ve taraftar bulmuştur. Kendisinden sonra gelen talebelerinden İmam Ebu Yusuf'un kadilık makamına geçmesiyle hocasının görüşleri daha da önem kazanmış, yöneticiler de Hanefi mezhebini resmi mezhep kabul etmişlerdir. Ebu Yusuf'un icra makamında olması ona avantaj kazandırmış, mezhebe olan rağbet nedeniyle hocasının görüşlerinin kitaplaştırılması ihtiyacı doğmuştur. Aynı dönemde İmam Muhammed de hocası Ebu Hanife'nin içtihatlarını yazıya geçirmeye ve çoğaltmaya başlamıştır. Onun kitaplaştırdığı görüş ve kanaatler rağbet görmüş ve Abbasilerin yönetimi altındaki coğrafyaya yayılmaya başlamıştır. Bu yayılma, öncelikle Irak, Şam, İran, Horasan üzerinden bugünkü Çin topraklarına kadar ulaşmıştır. Öte yandan, yine Abbasi iktidarına bağlı olan Mısır, İfrîkıye (Kuzeybatı Afrika) topraklarına kadar yayılmıştır. İslam dünyasındaki fetih hareketleriyle eş zamanlı olarak yayılan mezhebin ilkeleri, Sicilya'nın fethiyle birlikte, bu kez kendini bu topraklarda hissettirmeye başlamıştır. Aslında nerede insan varsa orada hukuka ihtiyaç vardır. Dolayısıyla, Müslümanların fethettiği topraklara zulüm değil, aynı zamanda gayr-i Müslimlerin, mühtedilerin, zimmîlerin tabi olacakları hukuk da götürülmüştür.

İnsan için yeme-içme ne kadar ihtiyaç ise hukuk ta o kadar ihtiyaçtır. Mezheplerin ortaya koyduğu ictihadlar genel manada insanın yaratıcısı, diğer insanlar ve insanın toplumla olan ilişkilerini düzenlerler. İşte, böylesine önem arzeden hukuk kavramı, diğer hukuk sistemlerinden farklı olarak İslam Medeniyetinde kendini ibadetlerin de yer aldığı amelî konular fikıh kavramı ve mezhep içinde tezahür ettirmiştir. Bu mezheplerin en meşhuru Hanefilik denilince genellikle Doğu coğrafyaları akla gelirken, bu mezhebin çok kısa süreli Batı'da da tanındığı zikredilerek konunun geçiştirildiği görülür. Halbuki Sicilya'da üç yüz yıla yakın takip edilen bu mezhebin serencamının bilinmesine ihtiyaç vardır.

Bu konuda "el-Arabu fî Sikılliyye”, "el-Müslimûne fî cezîrati Sikilya ve Cenûbi İtaliya” ve "el-Hayâtü'l-İlmiyye fî Sıkıliyyeti'l-İslâmiyye” başlıklı ve genel içerikli yayınların dışında, Borham Muhammed Atallah'ın “Tatbîku'ş-şeriati'l-İslamiyye fî Sikılyeti'l-İslamiyye ve'nNormandiye" başlıklı on sekiz sayfalık Sicilya'daki hukuk uygulamaları ve mezhepler hakkında Arapça makaleden başka Türkçe hiçbir çalışmanın bulunmaması, bu makalenin hazırlanmasına zemin teşkil etmiştir. Bu çalışmada, Hanefiliğin önce Kuzey Afrika'ya ulaşması, oradan da Sicilya'da yayılışını dağınık ve özet olarak ele alan bazı Arapça fıkıh tarihi çalışmalarının yardımıyla Sicilya ve Güney İtalya'ya Hanefi mezhebinin girişi, yayılma gerekçeleri, ömrü ve orada resmi mezhep haline getirilmesi ile zamanla terkedilmesi konusu incelenmeye çalış1lacaktır.

\section{Sicilya ve Müslümanların Sicilya'ya Geçişi}

Sicilya, orta Akdeniz’in en büyük adası olup coğrafi bakımdan İtalya'nın güneyinde yer alır. Latince yazılışı "Sicilia" iken bölgeye yakın Mısır lehçesinde "cim" harfi yerine "kaf" harfinin kullanılması nedeniyle tüm Arapça kaynaklarda "sıkılliye, sıkliyye / صقي" ya da Latince okunduğu şekliyle “سيسليا" şeklinde yazılmıştır". Bu adaya ilk defa Fenikeliler, ardından Yunanlıların hâkim olduğu ve Yunanistan'a yakınlığı sebebiyle de Helen kültürünün etkisinde kaldığı belirtilir. Daha sonraları, Sicilya'ya Romalılar, Vandallar ve Bizanslıların egemen olduğu kaydedilir.

Sicilya'ya ilk İslam akını h.31 (652) y1lında Suriye Valisi Muâviye b. Ebu Süfyân tarafından gerçekleştirildiği, Emevî hilâfetinin başına geçtikten sonra yeniden h.47/667'de Misır donanmasını Sicilya'yı fethetmekle görevlendirdiyse de başarılı olamadı. Emevîler'in son yıllarına kadar, özellikle İfrîkıye ve Mağrib Valisi Mûsâ b. Nusayr tarafından birçok sefer düzenlendiyse de yine Sicilya elde edilemedi. Bizans'ın bölgede güçlü bir donanma bulundurması sebebiyle Abbâsîler'in ilk yıllarında herhangi bir askerî harekât yapılamadı, ancak adayla olan ticarî ilişki sürdürüldü. ${ }^{2}$

\footnotetext{
${ }^{1}$ Abdülvehhab Hallaf, Hulasatu tarihi't-teşri'il-İslami, (Kuveyt: y.y., ts.), 87.

2 Ahmet Tevfik Medeni, el-Müslimûne fì cezîrati Sikilya ve Cenûbi İtaliya, (Tunus: Mektebetü'l-İstikame, 1365), 26; Mahmut H. SSakiroğlu, "Sicilya", Türkiye Diyanet Vakfı İslam Ansiklopedisi, (Ankara: TDV Yay., 2009), $37: 138$.
} 
Müslümanların kıta Avrupa'sına üç farklı cepheden ulaştıkları kaydedilir. Bunlardan ilki 710 tarihinde Cebel-i Tarık boğazından İber'e çıkıştır. İkincisi 827 yılında başlayan Sicilya'nın fetih süreci, üçüncü çıkış noktası ise Balkan coğrafyasıdır. ${ }^{3}$ Sicilya adası, Kayrevan'ın deniz tarafından İtalya'ya en yakın yeri olması hasebiyle Müslümanlar orta Avrupa'ya buradan çıkmışlardır. Günümüzdeki ölçümle 140 km'lik deniz yolu mesafesinin o günkü deniz gücü imkanlarıyla üç günde (14-17 Haziran 827) Tunus'tan Sicilya'ya ulaşı1dığ ve bu fetih için hazırlanan deniz gücünün 100 gemi, 700 at ve 10.000 askerden oluştuğunu yazan kaynakların ${ }^{4}$ verileri incelendiğinde, her gemiye yüz asker ve yedi atın sığabileceği kadar büyüklükte olduğu, o günün şartlarında gemi teknolojisinin küçümsenemeyecek kadar ileri düzeyde olduğu söylenebilir.

Sicilya, Kuzey Afrika yani bu günkü Tunus'ta iktidarda olan Ağlebîler (800-909) döneminde ve 1091'deki Norman istilasına kadar 200 yılı aşkın bir süre Müslümanların idaresinde kalmıştır. İslâm kültür ve medeniyeti Sicilya'da önemli gelişmeler kaydetmiş ve Ortaçağ Avrupası'nı özellikle bilim, kültür ve medeniyet alanlarında doğrudan etkilemiştir. ${ }^{5}$

Müslümanların Avrupa'ya geçiş noktalarından ilk ikisini oluşturan Endülüs ile Sicilya'nın fethi arasındaki fark vardır: Araplar İspanya'da önlerinde kendi gücüne dayanan son derece zayıf, düzenli bir ordusu olmayan mahalli bir yönetimle karşılaştılar. Sicilya'da ise durum bunun tam tersi idi. Burada, Doğudan Batıya uzanan topraklarında farklı milletlerin bulunduğu ve denizleri dolduran donanmasıyla önlerinde duran bir imparatorlukla karşılaşmışlardır. ${ }^{6}$

Hz. Osman devrinde başlayan, daha sonraki dönemlerde yaklaşık olarak yüz yıl boyunca devam eden Sicilya'yı fetih hareketleri çeşitli tarihlerde de devam etti. Farklı zamanlarda yapılan deniz ve kara savaşları sonunda Sicilya'nın bir kısmı, ilk defa Ağlebîler zamanında 827 yllında, Hanefi ve Maliki mezhebini de müctehid seviyesinde iyi bilen kadî ve fakîh Esed b. Furat komutasındaki ordu tarafından fethedilmiştir. Sonuçta Sicilya'nın tamamı Ağlebîler tarafından m.827'de başlatılan ve m.902 yılına kadar devam eden fetih harekâtı sonunda fethedilebildi. ${ }^{7}$ Bu fetihlerin amacı 1̂lây-1 kelimetullah olunca, yerli halka muameleleri de yumuşakça ve hoşgörüyle olmuştur. Ruhbanlığın olmadığı, adalet ve muhabbet ilkesini benimseyen bu yeni din, yerli halkın birçoğu tarafından benimsenmiştir. Ayrıca, Ağlebîler fetihten sonra hızla adanın imarına ve İslâm kültür ve medeniyetinin adaya yerleşmesine çalışmışlardır. İlkokul mahiyetinde kurdukları Ketâtib’ler ile adadaki Müslüman halkın çocuklarına Arapçayı, dini bilgileri ve Kuran-1 Kerîm’i öğretmişler, mescitler inşa ederek buralarda hem ibadet edilmesini hem de ileri seviye din eğitimi çalışmaları yapılmıştır. ${ }^{8}$

\section{Sicilya'nın Fethi Döneminde Mezhep Olgusu}

İslam Dünyasında bu günkü anlaşılan manada "mezhep" kavramı ve "mezhepleşme" ilk iki yüz yıl bulunmamaktadır. Hicri üçüncü asırdan itibaren Müslümanlar, sadece belirli bir mezhebin/müctehidin görüşlerini taklid etmeye başladılar. Bu dönemde müctehidlerin kanaatlerini anlayabilecek, onları birbirinden ayırt edebilecek ve maslahata en uygun olanı tercih edebilecek alimler öncülüğünde ve küçük gruplar halinde kendilerinden önce yaşayan ve ahlakına, ef'âline, takvasına güvendikleri kimselerin fetvalarına göre amel etikleri belirtilir. ${ }^{9}$

Mezhep kelimesi, Arapçadaki "ze-he-be" köklerinden türeyen ve lügavî yani gündelik manada "seyir ve mürur" anlamında "gitmek" olarak tercüme edilse de hem maddi bir gitme ve hareketliliği hem de insan aklının hareketliliği manasında bir düşünceye, bir fikre, bir kanaate meyletme" manalarına da gelmektedir. ${ }^{10}$

\footnotetext{
${ }^{3}$ Sigrid Hunke, Allahs Sonne über dem Abendland: Unser Arabisches Erbe, (Hamburg: Deutsche Verlags-Anstalt, 1960), 270; Mehmet Azimli, "Sicilya'daki İslâm Medeniyetinin Avrupa'ya Etkileri” İstem Dergisi 17, (Konya 2010). ${ }^{4}$ Moreno, Sicilya'da Müslümanlar, trc. Abdulhalik Bakır- Aydın Çelik, Fırat Üniversitesi, Orta Doğu Araştırmaları Dergisi 5/1, (2007), 173.

5 Ebû Zeyd Veliyyüddin Abdurrahman b. Muhammed İbn Haldun, (ö. 808/1406), Kitâbü'l-iber ve divanü'l-mübtede ve'l-haber fì eyyami'l-Arab ve'l-Acem ve'l-Berber ve men âsarahum min zevi's-sultani'l-ekber, (Beyrut: Daru'lFikr, 1992), 7 cilt, 3: 122; Philip K. Hitti, Arap Tarihinin Mimarları, trc. Ali Zengin, (İstanbul: Risale Yayınları, 1995), 93.

${ }^{6}$ Martino Mario Moreno, Sicilya'da Müslümanlar, 166.

7 İbn Haldun, Kitâbü'l-iber, 3:125; İhsan Abbas, el-Arabu fì Sikılliyye, (Beyrut: Daru's-sekâfe, 1975), 34.

8 Ali b. Muhammed b. Sa'î̀ ez-Zehrânî, el-Hayâtü'l-İlmiyye fi Sikilliyyeti'l-íslâmiyye, (Mekke: İhyâu't-türasi'l-Arabî, 1993), 201.

${ }^{9}$ Ebu Talip Mekkî, Kûtü'l-Kulûb, (Kahire: Daru'r-reşad, 1961), 324.

${ }_{10}$ Cemaluddin Muhammed b. Mükerrem İbn Manzur,(ö.711/1311), Lisanü'l- Arab, I-XV, (Beyrut, y.y., 1955),
} 
Hz. Peygamber dönemi ve daha sonraki birinci asırda "mezheb" kavramı pek fazla kullanılmazken, Asr-1 Saâdet sonrası "hilafet makamı" liyakatsiz kimselerin eline geçince, bunlar alimlerden yardım istemişler, hatta Ebu Hanife, İmam Malik, İmam Ahmed b. Hanbel gibi zatlar bu kötü gidişata ortak olmak istememişler, idarecilerin bu zaafları, insanları alimlerin kanaatlerine sarılmaya sevk etmesi neticesinde, önceleri "taklid" kelimesi, daha sonraları ise yavaş yavaş "mezheb" kelimesinin kullanılmaya başlandığı görülür. Akabinde de mezheplerin oluşmasina bu kanaatlerin etkisinin olduğu belirtilir. ${ }^{11}$ Bu yönüyle itikadî manadaki "fırka" ile "amelî" manada kullanılan "mezhep" kavramlarının tam da burada farklılaştığ1 görülür. Fırkada, birbirine rakip ve birbirinin görüşünü beğenmeyen iki grup varken, diğerinde ise birbirinin görüşüne alternatif veya farklı yorum manası bulunur. Daha sonraları bu iki kavramdan mezhep kelimesi, her iki manayı kuşatacak şekilde yayıldığı anlaşılmaktadir.

Kur'ân-1 Kerîm'de “zehâb” kökü çeşitli türevleriyle birçok ayette yer almakla birlikte12 doğrudan mezhep kelimesine rastlanmazken, Müslümanlar bu kelimeye çok özel bir mana yüklemişlerdir.

İlk iki asırda belirli bir mezhepten ziyade, şahıs merkezli bir taklid dönemi yaşandığ1 için, farklı bölgelere hicret etmiş sahabe, tabiîn ve daha sonraki fukahânın her birinin etrafında insanlar kümelenmiş, böylece bu günkü manada beş yüzü aşkın mezhep meydana gelmiştir. ${ }^{13}$ Daha sonra bir mezhebe bağlilık, onu taklid etme veya mezheplerin istikrar bulmasının temelinde "hukuk güvenliğinin sağlanması ve hukukta istikrar" olduğu söylenmektedir. ${ }^{14}$ Mezheplerin varlığının bireysel ve toplumsal planda tutarlılık ve bütünlüğü temin dişında olumlu etkileri de olmuştur.

Vahyin kaynağına ve etki ettiği topraklara oldukça uzak mesafede ve coğrafyası, bitki örtüsü, kültürü bakımından farklılık arzeden Kuzey Afrika'nın fethi Müslümanlar için her sahada yeni bir başlangıç olmuştur. Hz. Peygamber, (sas) yeni yerler fethedildiği oralara tebliğ heyetleri ya da muallimler gönderirdi. İslam dinini uzak bölgelere tanıtma heyecanı olan birçok sahabe ve tabiîn de bu kutlu vazifede görev almışlardır. İstanbul fethedilmezden önce Ebu Eyyub el-Ensari hangi gaye için İstanbul'a gelmişse, sahabeden de Müneyzir el-Yemânî ile tabiinden de Musa b. Nusayr(d.19/640-ö.99/717), önce Kuzey Afrika daha sonra da Endülüs bölgesine ulaşmışlardır. ${ }^{15}$ Ukbe b. Nâfi' İfrîkıye’ye girdiğinde yanında 25 sahabenin olduğu $^{16}$ ve buraya yerleşen sahabelerin Müneyzir el-Eslemî, ${ }^{17}$ Abdullah b. Üneys el-Cühenî (ö. 54) ${ }^{18}$, Ebû Risme el-Belevî ${ }^{19}$ ve Ebû Zem'a el-Belevî ${ }^{20}$ oldukları kaydedilir. Bu fetih ruhunu kavramış şahıslar, ileride kurulacak devletin idarî, dinî, adlî, siyasi vb. işlerinde hep en ön safta yer almışlar, bunların soyundan gelen birçok ilim erbabı da İslam medeniyetinin gelişmesine katkıda bulunmuşlardır.

Gündelik meseleler için çözüm üreten mezhepler henüz bir mezhep olarak ün salmamışken, Emevi halifeleri tarafından Hz. Peygamber'in yaptığının biraz geliştirilmiş hali denilebilecek bir “adliye teşkilatı” veya hukuk örgütü yürürlüğe konmuştu. Çünkü o sağlığında ashabının içtihat etmesine örneklik ettiği gibi onların içtihat etmelerine de müsaade etmiş, en azından ashabının fetva vermesini yasaklamamışt1. ${ }^{21}$ Bunu örnek alan Emevi halifeleri ve onların valileri tarafından atanan kadılar da, halifelerin bir nevi hukuki

3: 1522, "zhb” mad; Muhibbuddin Ebi Feyz es-Seyyid Muhammed Murtaze el-Huseyni Zebidî, Tâcü'l-arûs min cevâhiri'l-kâmûs, 40 cilt, (Kuveyt: Matbaatü Hukûmetu'l-Kuveyt, 1987), 2: 449.

${ }^{11}$ Muhammed Abduh, Muhaveratu'l-muslih ve'l-mukallid, trc: Hayrettin Karaman, Gerçek İslam'da Birlik, (Ankara: DİB Yay, 1996), 13.

12 Muhammed Fuad Abdülbâki, el-Mu'cemu'l-Müfehres li elfazi'l-Kur'ani'l-Azîm, (Beyrut: Dârü'1-Ma'rife, 1945), 276.

13 Hayrettin Karaman, Dört Risale, (İstanbul: İz yayınc1lık, 2000), 15.

${ }^{14}$ Ferhat Koca, "Mezhep”, Türkiye Diyanet Vakfi İslâm Ansiklopedisi (Ankara: TDV Yayınlar1, 2004), $29:$ 536.

15 Ebü'l-Hasan İzzüddîn Alî b. Muhammed İbnü'l-Esîr, (ö. 630/1233), Üsdü'l-gâbe fî Ma'rifeti's-sahâbe, 7 cilt, (Beyrut: Dâru'l-Kütübi'l-İlmiyye, 1433/2012), 5: 266; Ebü'l-Fazl Şihâbüddîn Ahmed b. Ali İbn Hacer El-Askalânî (ö. 852/1449), el-İsâbe fî Temyîzi's-sahâbe, thk. Ahmet Abdülmevcûd, Ali Muhammed Muavviz, 8 cilt, (Beyrût: Dâru'l-Kütübi'l-ìlmiyye, 1415/1995), VI: 227.

16 Ebu'l-Arab, Muhammed b. Ahmed et-Temimî, (ö. 333/945), Kitabu Tabakâtu Ulemâ-i Ifrîkiyye, (Beyrut: Dâru'lKitâbi'l-Lubnânî, ts.), 18.

17 İbnü'l-Esîr, Üsdü'l-Ğâbe, 5: 266; İbn Hacer, el-İsâbe, 6: 227.

18 İbn Hacer, el-İsâbe, 6: 17.

19 İbnü'l-Esîr, Üsdü'l-gâbe, 6: 111; İbn Hacer, el-İsâbe, 7: 140.

20 Temimî, Tabakâtü Ulemâ-i İfrikiyye, 17; İbnü'l-Esîr, Üsdü'l-gâbe, 6: 122.

21 İbrahim Selkînî, El-Müyesser fì usuli'l-Fıkh, (Dubai: Daru'l-irşad, 1990), 37. 
sekreterleri gibi Kur'an hükümlerini nazar-1 itibara almak suretiyle örf ve adet üzerine de dayanarak kendi görüşlerine (re’y) göre hüküm veriyorlard1. Bu durum, mezheplerin teşekkül edeceği zamana kadar devam etmiş, Endülüs'te de kadılar hukuki ve dini meseleleri bu şekilde çözmeye gayret etmişlerdir. ${ }^{22}$

Yeni fethedilen beldelerde kitleler halinde gönüllü ya da kerhen İslam'a giren topluluklarla Müslümanlaşan coğrafyada, Müslüman olanlarla Müslümanların hakimiyeti altında yaşamayı kabul eden zimmîler arasındaki muameleler ve yerleşik teamüllerle karşı karşıya kalan müçtehitler, karşılaştıkları yeni örf ve adetin bir kısmını kabul etmişler, bir kısmını ise aykırı bularak yeni çözümler üretmişlerdir. ${ }^{23}$

Temel dini bilginin haricinde çok fazla bilgiye sahip olmayanlardan oluşan mücahitler topluluğunun Afrika topraklarında uzun süre kalması için askeri gücün dişında başka ihtiyaçları da gündeme taşımıștı. Dolayısıyla sadece askeri sahada becerikli olan komutanların yanında insanî ve İslamî alanda da donanımlı ve yetişmiş insan kaynağına ihtiyaç duyuluyordu. Şüphesiz, siyasî ve hukukî oluşumları etkileyen diğer faktörlerden, içinde yaşanılan coğrafya, kültür ve sosyal şartlar da yeni ihtiyaçları hep canlı tutmuştur.

Misır ve Kuzey Afrika'nın fethinden itibaren ve daha sonraki dönemlerde "fetih hukuku, yani esirlere nasıl muamele edileceği, ganimetlerin paylaşımı, toprak yönetimi, idari yapının dizaynı, Müslümanlarla gayr-i Müslimler arasındaki beşeri münasebetlerin tanzimi, evlenme, boşanma, ticari hayat vs." gibi hayatın tümünü kuşatan muameleler için hukuka ve hukukçulara/kadılara ihtiyaç duyulacağı muhakkaktır. Tam burada, yaşanan ve ileride yaşanması muhtemel olayları çözmek üzere fakih sahabe ve tabiîn'in daha önce verdikleri ictihadlar ve fetvalar yöneticiler için kurtarıcı güç mahiyetinde idi.

Öte yandan, Mısır ve İfrîkıye fethinin başladığı 650 yılında ilk mezhep imamı sayılan h.80/699 doğumlu İmam-1 Azam, Afrika topraklarının daha sonra tanıyacağı ilk mezhebin kurucusu h.88/707 doğumlu İmam Evzaî ve h.93/712 de doğumlu İmam Malik de henüz dünyaya gelmemişlerdi. Fakat, yaşanmakta olan fetih süreci ve acil ihtiyaç duyulan yeni olaylar karşısında içtihat ehline ihtiyaç duyuluyordu. Bu durumda, mezhep imamlarını yetisstiren silsiledeki hocalar durumundaki sahabe, tabiîn ve tebe-i tabiîn'den fakih olanların verdikleri hükümler, Afrika fatihleri ve idarecileri için acil olarak istifade edilebilecek hazır fetvalardı. Dolayısıyla, bugün anlașılan manada Afrika ve Sicilya'ya mezheplerin giriși ve taklid edilişi, zaman bakımından daha sonralara tekabül etmektedir. Kısaca, Irak, Hicaz, Şam'da mezhep olgusu ne zaman başladı ve yerleşti ise, Mağrib, Endülüs ve Sicilya topraklarında da o zaman yerleşmeye başladı denilebilir. Bu sebeple bu döneme "çok mezhepli dönem" ya da "mezhep olmayan dönem" denilebilir. Çünkü bu dönem, mezheplerin oluşum dönemlerinin başlangıcında olunması sebebiyle, kıyas ve re'yi önceleyenler manasındaki "ehli rey" ile nassları önceleyenler manasındaki "ehl-i hadis" ekolleri olarak tanınan bir dönemdi.

$\mathrm{Bu}$ sebeple ilk kaynaklarda, Hanefi mezhebi yerine daha çok bölge adı, mesela "Kûfiyyûn" ya da "Irâkıyyûn" gibi kavramlara rastlanır. ${ }^{24}$ Dolayısıyla, ilk dönem fikıh merkezleri Irak, Hicaz, Suriye ve Misır hukuk okulları/ekolleri olmak üzere dört merkezde toplandığ 1 için bu isimler daha meşhurdu. Malikiliğin Kuzey Afrika, Endülüs ve bir dönem Irak’taki varlığı; Şafiiliğin Mısır ve çevresinde, kısmen de Horasan'daki gelişimi yanında Hanefiliğin değişik coğrafi bölgelerdeki dağllımı hep buna işaret etmektedir. ${ }^{25}$

Müslüman coğrafyacı Makdisî de (ö. h. 390/999?) eserinde yalnızca fizikî coğrafyaya dair bilgiler vermekle kalmaz, aynı zamanda sosyal, ekonomik, kültürel ve mezhep konularını ilgilendiren ve günümüzde "beşerî coğrafya" denilen konular hakkında da bilgi verir. ${ }^{26}$

Makdisî, İslam coğrafyasını "iklim" kavramıyla çeşitli bölgelere ayırmış; bu bölgeleri de önce Müslüman Arapların yaşadıkları yerler olan "Arap yarımadası, Irak, Akûr, Şam, Mısır ve Mağrib" beldelerini Arap (ekâlîmü'l-Arab) şeklinde isimlendirmiştir. Arap olmayan Müslümanların yaşadığı yerleri ise (ekâlîmü'l-acem) olmak üzere şöyle isimlendirerek, buranın Meşrık (Horasan), Deylem (Cürcân), Rihâb (Azerbaycan,), Cibâl (Batı İran),

\footnotetext{
22 Robert Mantran, İslamın Yayılış Tarihi, trc. İsmet Kayaoğlu, (Ankara: A.Ü. İlahiyat Fak. Yayınları, 1981), 188.

${ }^{23}$ Hayrettin Karaman, Anahatlariyla İslam Hukuku, (İstanbul: Ensar Neşriyat, 2011), 1: 52.

${ }^{24}$ Temîmî, Kitâbu Tabakâti Ulemâi İfrîkiye, 1: 180.

${ }^{25}$ Murat Şimşek, Mezhepleşme Sürecinde Hanefilik, (Konya: y.y., 2014), 30.

${ }^{26}$ Marina A. Tolmacheva, "Makdisî”, Türkiye Diyanet Vakfı İslam Ansiklopedisi, (Ankara: TDV Yay, 2003) $27: 432$.
} 
Hûzistan (Mezopotamya'nın doğusu), Fars (eski İran), Kirmân (İran'ın güneyi) Sind (Hint yarımadası) mıntıkalarından oluştuğunu belirtmiştir. ${ }^{27}$

Makdisî bu iklimleri/bölgeleri incelerken "küver" (vilâyetler), kasabalar (kasabât), şehirler (müdün), metropoller (mısr), semtler (nahiye), yöreler (kura) şeklinde alt taksimatta bulunmuştur. ${ }^{28}$

Makdisî'nin, coğrafî mekânları taksim ederken esas aldığı bu terimlerin tespitinde "fikıh usulü"nün verilerinden yararlandığ 1 ve böylece coğrafya ilmine yeni ve farklı bir metodolojik yaklaşım kazandırdığı görülür. O, bilgi aktarımında bulunduğu hemen her bölgede hangi mezheplerin kabul gördüğünü ve hangilerinin müntesibinin bulunduğunu zikretmesi, hicri III.-IV. (X.) yüzyılda fikıh ekollerinin aktüel durumunu açısından önemlidir. Dolayısıyla Makdisî̀nin fikhı ilgilendiren konulardaki tespitlerinin hem coğrafya hem de fikıh ilmine olmak üzere çift yönlü bir katkı sunduğu söylenebilir. ${ }^{29}$

Makdisî, coğrafi bölgelerden Sicilya'yı da ilgilendiren "iklîmu'l-Mağrib" bahsinde "nasıl 'Maşrık' denilince iki ayrı mıntıka olan 'Haytal ve Horasan' anlaşılıyorsa, Mağrib de aralarını denizin ayırdığı "İfrîkıye" ve "Endülüs"ten oluştuğu için iki yakayı birlikte zikrettik" diyerek, ${ }^{30}$ Sicilya hakkındaki bilgileri bu başlıkta aktarmıștır. Bu bölgelerdeki mezhep anlayıșını ve Endülüs'te İmam Şafii'nin görüşlerini kabul etmeme şeklindeki mezhep taassubunu ve Malikilik ile Hanefiliğin meşhur olmasına dair haberleri burada naklederek, ${ }^{31}$ mezhep olgusunun coğrafyaya tesirinden bahseder.

Osmanlı dönemi yazarlarından Mahmûd Kefevî de(ö. 990/1582), kendi yaşadığı döneme kadar Hanefîliğin coğrafì açıdan izlediği serüvenini anlatır. Kefevî, Hanefîliğin yayıldığı muhitleri coğrafî açıdan tasvir etmekte, ${ }^{32}$ fakat Kuzey Afrika, Sicilya ve Endülüs'e dair görüş bildirmemektedir. Vefat tarihi dikkate alındığında onun Kuzey Afrika ve Müslümanların oradaki varlığından haberdar olmamasına imkan yoktur. Belki onun yaşadığı döneme kadar, önce 1091'de Sicilya'da Müslüman varlı̆ğ sona ermiş, ardından 1492'de Endülüs'teki Müslüman varlığı da sona ermiş olması nedeniyle saymamış olabilir. Ya da Endülüs'te Hanefiliğin ömrünün kısa sürmesi ve Endülüs denilince akla Malikî mezhebinin gelmesi nedeniyle zikretmemiş olabilir.

Mezheplerin nereye ve nasıl yayılıșı ne olursa olsun hicri ilk iki asırda bugünkü manada mezheplerin bulunmamas1, yeni karşılaşılan sorunları ihmal etmeyi gerektirmemiştir. Bu sebeple İslam tarihinde "komutan-kad1-müftü" üçlüsü devlet yönetiminde büyük görevler üstlenmiştir. Bu sebeple mezheplerin oluşuma kadı ve müftülerin görüşleri yansıdığı için, mezheplerin temelini hukukî olaylar ile ibadet hayatındaki meseleler oluşturmuştur. Şimdi, İslam tarihindeki, adaletin işleyişi ve tarihçesi hakkında bilgi aktarmak istiyoruz:

\section{Mezhepler Öncesinde Kazâ ve İftâ Faaliyeti}

Arapça 'da "bir şeyi yerine getirmek, îfâ etmek, iki şeyin arasını kesin olarak ayırmak" gibi manalara gelen "kadâ-kazâ kelimesi, İslam adliye teşkilatında özel bir manada kullanılmıştır. 33 O da insanlar arasında meydana gelen anlaşmazlıkların ve hak ihlallerinin çözülmesi ve suçluların cezalandırılması hususunda karar veren manasıdır. Bu durum toplu halde yaşamanın bir gereğidir.

Bu nedenle, İslam Hukukunda "kad1l1k" ya da "yargılama hukuku" da Hz. Ömer'in, Basra valisi Ebu Musa'l-Eşari'ye yazdığı ve İslam yargılama hukukunun temelini teşkil eden, fakihler arasında da "Kitabu siyâseti'l-kazâ" ismiyle meşhur olan "Şüphesiz kaza (yargı) muhkem bir farz ve uyulması gereken bir sünnettir" ifadesi sebebiyle faziletli bir iş olarak kabul edilir. ${ }^{34}$ Mevsilî "adalete uygun hüküm vermek vazifelerin en üstünü ve ibadetlerin en

\footnotetext{
${ }^{27}$ Makdisî, Ahsenü't-tekâsîm, 9-10.

${ }^{28}$ Makdisî, Ahsenü't-tekasim, 9.

${ }^{29}$ Münteha Maşalı, "Makdisî’nin Ahsenü’t-Tekâsim’i Bağlamında Fıkıh Coğrafyası/Fıkhın Coğrafyası”, Usûl İslam Araştırmalari Dergisi 25, (2016 25), 63-106.

30 Makdisî, Ahsenü't-tekâsîm, 235.

${ }^{31}$ Makdisî, Ahsenü't-tekâsîm, 236.

32 Simşek, Hanefilik, 34.

${ }^{33}$ İbn Manzur, Lisanu'l-Arap, "k-d(z)-y" maddesi, 15: 186,

${ }^{34}$ Kasanî, Alauddin Ebu Bekr b. Mes'ud, Bedaiu's-Sanai' fi tertibi'ş- Şerai', 7 cilt, (Beyrut: Dâru'1-Kütübi'1-i̇lmiyye, 1988), 7: 117.
} 
şereflisidir" derken, ${ }^{35}$ Mülteka şerhi Mecmeu'l-Enhür'de de "hak ile hükmetmek, farzların en kuvvetlilerinden ve Allah'a imandan sonra ibadetlerin en faziletlilerindendir" denilir. ${ }^{36}$

Nitekim, Hz. Âdem'den itibaren bütün peygamberlerin gönderiliş sebeplerinden en önemlisi adaleti tesis etmek ve insanlar arasında 'adaletle hükmetmek'tir. Allah'in Hz. Âdem'e yeryüzünde halifelik görevi vermesi, Hz. Davud'a da "Ey Davud! Biz seni yeryüzünde halife yaptık. O halde insanlar arasında adaletle hükmet..." (Sad, 38: 24) buyurması, onun yürüttüğü yargı görevinin önemini ifade etmesi sebebiyle, İslam adliye Teşkilatı için de bir nüve sayılmıştır. Hz. Peygambere de "Allah'ın sana gösterdiği şekilde insanlar arasında hükmedesin diye sana kitabı hak ile indirdik; hainlerden taraf olma!" (Nisa, 4: 105) buyurarak, Peygamber'den adalete yansıyan işleri hakkaniyetle yerine getirmesini istemisstir. $\mathrm{Hz}$. Peygamber de başlangıçta yargi-kadılık görevini "bizzat kendisi" yönetirken, daha sonra sahabeden bazılarını yargı faaliyetlerini yürütmek için değişik şehirlere göndermiştir. ${ }^{37}$ Medine'deki işlerin çoğalması üzerine Hz. Ömer, Hz. Ali, Zeyd b. Sabit ve Ebu Musa el-Eş'ari de Hz. Peygamber'in sağlığında kadılık yapmışlardır. ${ }^{38}$

Hz. Peygamber (sas)'in Yemen'e Muaz'ı gönderirken yaptığı gibi, Hz. Ömer de hilafeti zamanında Kûfe, Kadisiye, Medâin, Basra şehirlerine vali ve kadılar atamıștır. Kûfe kadılarının en messhuru ise Hanefi mezhebinin temel tasslarından olan Abdulah b. Mes'ud'dur. $\mathrm{O}$ hem kadılık hem de eğitim işleriyle uğraşmış ve Hz. Osman zamanında da görevine devam etmiştir. Hz. Osman ve Hz. Ali de vali ve kadılar atamaya devam etmişler bir yanda da kendileri de zaman zaman üst düzey meselelerde hakemlik yapmışlar ve kendi ictihadlarını bir kitapta toplamıştır. ${ }^{39}$ Emeviler ve Abbasiler döneminde de aynı uygulama devam etmiştir.

Özellikle Ömer b. Abdülaziz, yıpranan adliye teşkilatını yeniden düzene sokmak için kadı ve valilere bazı tedbirler ve nizamnameler gönderdi. Onların halledemediği durumlarda büyük fakih Said b. El-Müseyyeb’ten destek alığı kaydedilir. ${ }^{40}$ Bazı kadıların Cuma günleri halka vaaz ettikleri ve Cuma imam ve hatipliği yaptıkları da rivayet edilir. ${ }^{41} \mathrm{Bu}$ sebeple belki de peşinen "İslam kadılar ya da kadılık müessesesi ile dünyaya yayılmıștır" cümlesi kurulabilir. Çünkü kadıların içtihatları ve verdikleri kararlar, öncelikle kendi içtihatlarının daha sonra da takip ettikleri mezhep imamlarının görüşlerinin kök salmasında etkili olmuştur. Ayrıca hüküm verirken takip ettikleri yöntem, kendilerinden sonrakilere örneklik teşkil etmiştir. En önemlisi kadılıktan çeşitli gerekçelerle uzak duran fakihlerin görüşlerinin, icra makamındaki kadılar tarafından bu içtihatların karar esnasında kullanılmaları ve yazıya aktarılmalarıdır.

Fetih gerçekleştiren Müslüman idareciler, fethedilen bölgede henüz idari teşkilatlanmasını tamamlamadan önce, Hz. Peygamber, Hz. Ömer'in ve diğer halifelerin yaptıkları gibi maddi ve manevi bakımdan toplumu ayakta tutacak olan "cuma imam ve hatipliği" ile "kadılık müessesesi"ni acilen ihdas etmişlerdir. İmamlar, toplumu ahlaken eğitmeye ve suç oranının en düşük seviyede olması için va'z u nasihat ediyorlar, ibadetle ilgili konularda fetva veriyorlard1. Kadilar ise modern manada mahkemelere intikal eden bireysel veya toplumsal vak'aları inceleyip adaleti temin etmeye çalışan kimselerdir. Daha sonraki kadılar da Muaz’ın, Ebu Musa ve Kadı Şureyh’in yaptıkları gibi, önce Kur’an ve Sünnetle fetva vermişler, bulamadıkları zaman ise kıyas yaparak içtihat etmişlerdir. Aksi halde yeni olaylara içtihat yoluyla çözümler üretilememesi, fikhın olayları takip edeceği yerde, olayların fikha uydurulmaya çalışılması tehlikesini doğurabilecektir. ${ }^{42}$

Kadılar, hem Kur'an ve Sünnet ile amel etmişler hem de bu ikisini anlamada kıyas metodunu tercih etmişlerdir. Bu manada kadıların mezhebi aynı zamanda o coğrafyanın da mezhebi olmuştur. Mesela, Abbasiler zamanında Harun Reşid’in kadılıkla görevlendirdiği

\footnotetext{
${ }^{35}$ Mevsilî, Abdullah b. Mahmud, El-íhtiyar li Ta'lil'il-Muhtar, 2 cilt, (M1sır: Daru'l-Fikr, ts.), 2: 82.

${ }^{36}$ Damad, Seyhzade Abdurrahman b. Şeyh Muhammed b. Süleyman, Mecmeu'l-Enhur, (İstanbul: Matbaa-i Amire, 1308), 2: 43.

${ }_{37}$ Aslan, Nasi, İslam Hukukunda Yargılama Etiği ve İlkeleri, (Adana: Seçkin yayıncılık, 2014), 7.

${ }^{38}$ Atar, İslam Adliye Teşkilatı, 50.

39 Atar, İslam Adliye Teşkilatı, 80.

${ }^{40}$ Atar, İslam Adliye Teşkilatı, 84.

${ }^{41}$ Atar, İslam Adliye Teşkilatı, 87.

${ }^{42}$ Atar, İslam Adliye Teşkilatı, 31; Köse, Saffet, İslam Hukukuna Giriş, (İstanbul: Kervan yay. 2012), 37.
} 
İmam Ebu Yusuf'un kadılık görevini üstlenmesi, Hanefi mezhebinin bu coğrafyada yayılmasına ve revaç bulmasına sebep olmuştur. ${ }^{43}$

Dört halife dönemi ile Emeviler ve Abbasiler döneminde fikıh henüz tedvin edilmediğinden bir başka ifadeyle konular ana başlıklara ayrılmadığından kadılar kendi şahsi içtihatlarıyla hükümler veriyorlar, anlaşılamayan ya da çözülemeyen hususlarda halifeye mektupla danışıorlard1. ${ }^{44}$

İslam'da kâdî olmak için kâdînın Müslüman olma şartı arandığından, Müslümanlara kafirlerin kâdîlı yapmaları dinen caiz değildir. Fakat, Ebu Hanife İslam toplumunda gayri Müslimlerin kendi aralarında kadî tayin etmelerini caiz görmüş ve birçok Müslüman devlette de uygulama bu şekilde gerçekleşmiştir. ${ }^{45}$ Sicilya'da Hanefiliğin kendisine zemin bulma gerekçelerinden birisi de budur. Adada, gayr-i Müslimlerle iç içe yaşayan Müslümanlar arasında yaşanan adlî vakalarda zaman zaman gayr-i müslim hakemler bulundurulmuş ya da gayr-i Müslimlerin hakemlik yapmasına müsaade edilmiştir. Hanefi mezhebinin maslahata uygun bu görüşü Osmanlılar zamanında da uygulamada kalmış ve Hristiyan halka aralarında yaşanan olaylarda kendi hukuklarını uygulamalarına izin verilmiştir ki, bu uygulama "örfì hukuk" olarak da isimlendirilmektedir. ${ }^{46}$

Kayrevan ve Sicilya'nın tarihinde de kâdîlar toplumun belki de en önemli şahsiyetleri olmuşlar, hatta Sicilya'yı fetheden komutan, aynı zamanda bir kâdî olan Esed b. Furat'tır. ${ }^{47}$ Fakat, halife/emir-kadı arasındaki kimin kime tabi olacağı tartışmaları sebebiyle zaman zaman ilim sahibi birçok kişi hem kâdîlı görevinin ağır sorumluluğu hem de halifelerin baskıları sebebiyle kâdîlık görevini kabul etmek istememiştir. ${ }^{48}$

Mağrib kâdîlarının ve nâiplerinin iyi eğitimli olanlardan seçilip bölgeye gönderildiği ya da eğitim aldırıldığı görülür. İfrîkıye'de görev yapan kâdîların eğitimleri bakımından sahabe ve tabiîn örneğinde olduğu gibi "Doğu'da yetişip Batı'ya gönderilenler" ve sonraki neslin yaptığı gibi “Batı'da doğup Doğu'da tahsil yaptıktan sonra tekrar Batı'ya dönenler" şeklinde ikiye ayırmak mümkündür.

Yeni fethedilen bir bölgenin, siyasî, kültürel, iktisadî ve bayındırlık gibi altyapılarının oluşturulmasının o bölgede ilmî gelişmelere ön ayak olma ile yakından irtibatı vardır. Dolayısıyla Mağrib bölgesinin bu süreci tamamlayıp ilme yönelmesi, kendi ilim adamlarını yetiştirmesi belli bir zaman almıştır. Bu sebeple öncelikle Doğu'dan ilim adamları, imamlar ve kâdîlar transfer edilmiştir.

İster Doğu ister Batı asıllı olsun her iki grupta da kadılar öncelikle Arapça, tefsir, fikıh ve hadis eğitiminden geçmektedir. ${ }^{49}$ Hadis ilmi ihtisas yapılan temel alanlardandır. Mesela, Endülüs kâdîlarına bakıldığında çoğunluğun Endülüs'te veya Doğu'daki medreselerde mutlaka hadis dersleri aldıkları ve rivayetlerde bulundukları görülür. Hadislerin fıkıhta delil olarak kullanışında muhaddis yönü temayüz eden kâdîların sayısı az olmakla birlikte, gelişme sürecinde ise daha fazla olduğu görülmektedir. 50

Kuzey Afrika ve Endülüs'te mezhep olgusunun henüz günümüzdeki kadar yaygınlaşmadığı zaman dilimini "Mezhepler Öncesi Dönem" olarak isimlendirerek konuya devam etmek istiyoruz.

\section{Sicilya'da Mezhepler Öncesi Dönemde F1kıh}

Mağrib’te kurulan ilk Müslüman şehri Kayrevan'ın tarihinin ve bu şehirde yetișen fakih ve kadıların hayatlarının bilinmesi öncelikle Sicilya daha sonra da Endülüs fikhının karakteri hakkında bilgi vermektedir.

\footnotetext{
${ }^{43}$ Hayrettin Karaman, İslam Hukuk Tarihi, (İstanbul: İZ yayınc1lık, 1989), 244.

${ }_{44}$ Atar, İslam Adliye Teşkilatı, 85.

45 Şirbinî, Mahmut, el-Kadâ fi'l-İslam, 2. Bask1, (Mısır, y.y., 1999), 20.

46 Yusuf Halaçoğlu, XIV-XVII. Yüzyıllarda Osmanlılarda Devlet Teşkilatı ve Sosyal Yapı, (Ankara: Türk Tarihi Kurumu, 1996), 119.

47 Ömer Faruk Habergetiren, "Fatih Bir Fakih: Ebû Abdullah Esed b. Furât b. Sinan (142-213/759-828), Hayatı ve F1kıh İlmindeki Yeri, "Harran Ün. İlahiyat Fakültesi Dergisi 27, (Ocak-Haziran 2012), 257.

${ }^{48}$ Bk. Ebû'l-Hasen b. Abdullah b. Hasen en- Nübâhî, Târîhu kudâti'l-Endelüs, (Beyrut: Dâru'l-âfâk, 1983), 55, 56, $110,188$.

49 Özdemir, Mehmet, Endülüs Müslümanlart-I, (Ankara: TDV Yay., 2010), 59-69.

50 Konu için bk. Öztoprak, Mustafa, "Endülüs Hadisçiliğinde Kadıların Yeri", Şırnak Ün-İlahiyat Fak. Dergisi 4, (Şırnak, 2013), 7: 105-122.
} 
Kuzey Afrika ve Endülüs fetihlerine komutan, kad1, imam vb. görevlerle katılan ilim ehlinin, ders aldıkları sahabe, tabiin ve tebe-i tabiinden öğrendikleri fetva ve fetva usulleriyle uygulamaya koydukları adliye teşkilatı ya da fetva usulleri inkar edilemez. Bu dönemde günümüzde taraftarı kalan dört beş mezhepten ziyade kadı, müftü ve cuma İmamlarının müstakil olarak oluşturdukları hukuki-adli uygulamaları ve içtihatları nevazil fikhı için yeterli idi. Bu dönemin h.25/647 yılında Hz. Osman döneminde Kuzey Afrika'yı fetheden Abdullah b. Sa'd ile başladığı söylenebilir. Kuzey Afrika'nın Fas'a kadar olan bölgesi ile Endülüs fethinin 710 da başladığı ve devletleşme sürecinin başlangıcının 755 yılı esas alındığında ve mezhep imamlarından Ebu Hanife'nin 768 de, İmam Evzaî'nin 774 de ve İmam Malik'in 795 de vefat ettiği dikkate alınırsa bu dönem en az 150 sene devam etmiştir. Tabii ki bu dönemde mezhep imamları hayatta olduklarından onlardan yüz yüze eğitim alan, onları ziyaret eden, ilim tahsil edip Kuzey Afrika ve Endülüs'e dönenleri bu dönemden hariç tutulamaz. Aslında bu dönem, bir yandan mezhebin bulunmadığı öte yandan mezhep imamlarının görüşlerinin yavaş yavaș bu coğrafyaya ilim seyahatine çıkan öğrenciler ve kitap nakilleri ile girdiği karma bir dönem olarak da zikredilebilir.

Öte yandan, fethedilen bölgelerde zuhur eden yeni hadiseler için yazışmaların yapıldığı, böylece meselelerin halledilmeye çalışıldığı görülür. Fıkhî yazışmaların Mısır'da fıkhın tekevvün dönemini ifade eden bu süreçte günümüze kadar intikal edenlerinin sayısı az olmakla birlikte daha çok kâdîların karşılaştıkları fikhî meselelerin çözümünde bir araç olarak kullanıldığı görülmektedir. Nitekim bu dönemin bazı fikhî yazışmalarına yer veren Kindî, özellikle Ömer b. Abdülaziz döneminde (h. 99-100) kadılık yapan İyaz b. Ubeydullah'ın fakih kimliği ile de tanınan Ömer b. Abdülaziz'e mektuplar yazarak, ondan diyet, şuf’a, borç ilişkileri gibi soruların cevabını talep ettiği yazışmalara yer verir. ${ }^{51}$

Sicilya'nın 827 de fethedildiği düşünüldüğünde, bu dönemde henüz mezhep taassubu bulunmadığından adaya ilk ulaşan Müslümanlar tek bir mezhepten ziyade farklı mezhep imamlarından ders almış fakih-kâdîları taklid ettikleri görülür ki, bu kâdîların başında Esed b. Furat gelmektedir. Hanefilik de onunla adaya ulaşmıştır.

\section{Sicilya'da Hanefilik}

Bir mezhebin yayılmasının temel sebepleri arasında, tedvin faaliyeti, öğrencilerin gayretleri ve kadıların içtihatları ve hukukta birliğin sağlanması için resmi mezhep olarak tanınma gibi gerekçeler sıralanır. ${ }^{52}$ Bunlar arasında Hanefiliğin Sicilya'da yayıllısıını en çok ilgilendiren husus kâdîların yargılama metotlarıdır. Kayrevan merkez olmak üzere İfrîkıye'de (bilâd-1 Mağrib) Ağlebî sülalesinin miladi IX. asır başlarından itibaren iktidara gelmesiyle birlikte mezhep imamlarının görüşleri de bu coğrafyaya girmeye başlamıştır. Bu zamana kadar kadıların karma mezhep anlayışı veya maslahata uygun her türlü içtihatlarla amel ettikleri görülür. Abbasilerin Bağdat'ta Hanefiliği resmi mezhep kabul etmeleri, Ağlebîlerin de Abbasi halifelerine bağlı olarak bu toprakları yönetmeleri sebebiyle karma ictihad uygulaması yavaş yavaş yerini Hanefi mezhebine bırakmış, başta adliye teşkilatı olmak üzere Hanefi fetva ve kazâlarına göre muamele yapılmaya başlanmıştır. ${ }^{53}$ İmam Ebu Yusuf'un başkadı olmasıyla birlikte Abbasi idaresindeki tüm vilayetlere Hanefi kadîlar atama uygulamas1, Sicilya'yı da etkilemiştir. Böyle olunca, bu topraklara gönderilen kadılar da tabii olarak Hanefi mezhebine mensup idiler. Bu durumun 827 yılından 909 yılına kadar, yani Fatımîlerin Ağlebîleri yıktığ1 tarihe kadar devam ettiği kaydedilir. Özellikle 827 yılında Sicilya topraklarına Osmanlı'daki isimlendirmeyle yani hem kadî hem asker/komutan "kazasker" olarak ulaștıktan ve orada bir y1l yaşadıktan sonra veba hastalığından vefat eden büyük fakih Esed b. Furat'in hatırasının orada yaşatılması da bunda etkilidir. ${ }^{54}$ Şimdi, Sicilya'ya Hanefiliğin geçişi ve yayılma sebeplerini izah ettikten sonra özellikle Hanefi mezhebi müntesibi olarak kadîlik yapan bazı şahısların hayatları hakkında kısa bilgi sunmak istiyoruz:

\footnotetext{
${ }^{51}$ Ebû Yûsuf Ya'kûb b. İshak el- Kindî, (ö.252/866), Kitâbü'l-vülât ve Kitâbü'l-kudât, (Beyrût: Matbaati'l-Yûsûiyyîn, 1908), 333-337.

52 Özel, Ahmet, İmam Ebu Hanife ve Hanefi Mezhebi, (Ankara: DİB yay, 2015), 55.

53 Abdülvehhab Hallaf, ìlm-i Usûli'l-Fıkh, (Misır: Mektebetü'd-da'veti'l-İslâmiyye, 1948), 256.

${ }^{54}$ Makdisi, Ahsenu't-tekasim, 244: Leonard C. Chiarelli, A History of Moslım Sicily, (MidseaBooks, y.y.,2011), 29,
} 


\section{Sicilya Kadıları ve Hanefiliğin Yayılmasına Katkıları}

Yukarıda da belirtildiği üzere kadılar, mezheplerin oluşumunda, yayılmasında ve geniş kitlelere aktarılmasında büyük role sahiptirler. Bu sebeple, Sicilya'ya Hanefiliğin tanıtılması ve orada uzun süre etkili olmasında kadilar hep ön plandadır.

Abbasîler döneminde İmam Ebû Yusuf'un "kadı'l-kudât" olarak tayin edilmesi, onun da yargıda birliği sağlamak için genellikle Hanefî kadılar ataması Hanefî mezhebinin çok geniş bir coğrafyaya yayılmasında etkili olmuştur.

Her ne kadar Hanefíliğin özellikle Irak ve Horasan diyarında, Mâlikî mezhebinin Hicaz'da yayıldığı sseklindeki genel kanaat doğru ise de aslında her mezhep Endülüs'ten Hindistan'a kadar İslâm coğrafyası üzerinde az veya çok tanınıp benimsenmiş, buna bağlı olarak da çeşitli şehir ve bölgelere farklı mezheplerden kadı tayin edilmiştir. Fakat, Abbasîler döneminde tayin edilen Hanefî kadı uygulaması, zamanla diğer mezhepler için de örnek teşkil etmiştir.

Hanefiliğin yayılma sürecinde belki de kısa kalmasına rağmen etkili olduğu coğrafya Mağrib diyarıdır. Makdisî, Sicilya halkının çoğunun Hanefì olduğunu ve Kuzey Afrika'da Hanefiliğin İmam Muhammed'in talebesi ve aşağıda özet halinde hayatı anlatılacak olan Kayrevan kadısı Esed b. Furat sayesinde yayıldığını, Endülüs'te de başlangıçta Hanefíliğin yaygın olduğunu, fakat Malikiler ile Hanefîler arasında ihtilâfın daha fazla büyümesini önlemek ve uygulamada birliği sağlamak için Hanefîliğin engellenip Mâlikî mezhebinin özel himaye gördügünü belirtir.55 Dolayısıyla, hem mezhepler öncesi dönemde müçtehitlerin görüşlerinin hayata geçirilmesinde hem de mezheplerin kuruluşlarını tamamladıktan sonraki dönemlerde kadılar hep ön planda olmuşlardır.

Kayrevan şehri, Makdisî’nin ifadesiyle bölgenin metropol şehri(mısr) haline geldiğinden, zamanla bu şehirde birden fazla mezhebi temsil eden kadıların görevlendirilmesi ihtiyacı hasıl olmusstur. Tarihi kaynaklarda bazı kadılar hakkında 'Kayrevan ve Sicilya kadısı' gibi ifadelerin bulunması ya da mezhep taassubu henüz oluşmadığı için "Kayrevan kadısı bir sene Hanefilerden bir sene Mâlikîlerden seçilmektedir"56 denilmesi veya kadıların mezhebi hakkında çok belirgin bir ayırıma tabi tutulmaması ve mesafe bakımından yakınlık sebebiyle Kayrevan kadılarının aynı zamanda Sicilya'nın hukukî işleriyle de ilgilendiklerini göstermektedir. Bazı kaynaklar, Sicilya'da Ağlebîler döneminde kadılık yapanların sayısını sekiz olarak zikretseler de ${ }^{57}$ gerçek rakamın bundan fazla olduğu kanaatindeyiz.

Makdisî'nin "Sicilya'nın çoğu Hanefidir" ifadesini eleştiren İhsan Abbas, "Makdisî, Sicilya'da Ağlebîler yıkılıp yerine Fatımîler hakim olduğu dönemde yaşamış ve bu bölgeyi ziyaret etmiştir. O dönemde hadis aleyhtarı olan Fatımîlerin lideri Şii Ebu Ubeyde ehl-i hadis olarak bilinen Maliki mezhebini yasaklamıștı. Bunun üzerine insanlar korkudan Malikiyiz demek yerine Hanefiyiz demeye başlamışlardı"58 diyerek, Hanefiliğin Sicilya'da gerçek anlamda etkili olmadığını ve zoraki bir durumla izah edilebileceği kanaatindedir. Halbuki, Sicilya'da Fatımîler dönemi ve daha sonraki dönemlerde Maliki kadıların atanmaya başlaması ve Hanefiliğin yerini Malikîliğe terketmesi gibi vakıalar dikkate alındığında Abbas'in görüşlerinin zayıflı̆̆ı ortaya çıkar. Çünkü, 909 da Kayrevan'da, 912 de de Sicilya'da hakimiyeti kaybeden Hanefi taraftarı Ağlebîlerden sonra işbaşına gelen Fatımîler döneminde Lokman b. Yusuf(ö.319/931) on dört sene, İbn Ebi Sabîh(ö.334/945) ve Ebu Said Halef b. Ebu Kasım(ö.430/1038) ${ }^{59}$ ve daha nice Maliki kadılar görev yapmışlardır. Eğer, Abbas'ın dediği gibi insanlar korkudan Hanefiyiz deselerdi, kanaatimize göre Maliki mezhebine mensup kadilar atanmaya devam etmezdi.

Öte yandan, "Kayrevan kadısı bir sene Hanefîlerden bir sene Mâlikîlerden seçilmektedir" ifadesi ve Makdisî'nin "Sicilya ahalisinin çoğunluğu Hanefidir" şeklindeki kaydı ile Sicilya'yı fetheden komutan Esed b. Furat'ın ömrünün sonlarında sıkı bir Hanefi olması gibi sebepler birlikte düşünüldüğünde, belki de adanın fatihi hatırına Ağlebî yöneticilerin Kayrevan'daki iki kadıdan Hanefi olanını Sicilya kadısı olarak görevlendirdikleri muhtemeldir.

\footnotetext{
55 Makdisî, Ahsenü't-tekāsîm, 237.

56 Makdisî, Aḥsenü't-tekāsî̀m, 238.

57 https://www.alukah.net/culture/0/82223/ (Erişim: 14.04.2019)

58 Abbas, el-Arabu fi Sik1lliyye, 96.

${ }^{59}$ Zehrânî, el-Hayâtü'l-İlmiyye fì Sikıliyyeti'l-İslâmiyye, 283.
} 
Yaklaşık yüz yıl süren bu dönemde görev yapan kadıların göreve başlayış ve bitiş tarihleri hakkında net bilgi bulunamadığından ya da birden fazla göreve atanma-azletme vuku bulduğundan detaylı tarih sıralaması verme imkanı bulunmamaktadır. Buna rağmen sırasıyla görev yaptıkları yılları dikkate almak suretiyle özetlemek istiyoruz:

\section{1. Esed b. Furat, Tahsil Hayatı ve Mezhebi}

Aslen Horasan bölgesindeki Nîşâburlu bir aileden olup 142 /759 y1lında Harran'da doğdu. Bu tarihte Mağrib’in fethinin üzerinden yaklaşık 110 sene geçmişti, yani Müslümanlar Kayrevan'a tamamiyla hakim olmuşlard1. 60

Abbasîlerin İfrîkıye valisi Muhammed b. Eş'as'in ordusuyla birlikte Kayrevan'a giden (144/761) Furât'in babası, ailesini de beraberinde götürdü. Burada beş yıl kalan aile daha sonra Tunus'a gitti. Esed dokuz yıl ikamet ettiği Tunus'ta Ali b. Ziyâd el-Absî'den fikıh dersleri ald1. 172/788 yılında hadis ve fikıh tahsili için doğuya seyahate çıktı. Medine'de Mâlik b. Enes'ten Muvatta'yı dinledi. Ders esnasında çok fazla soru soran Esed'e İmam Mâlik ehl-i re'yin temsilcisi olan Irak'a gitmesini tavsiye etti. Irak'a giderek Hanefi mezhebinin önemli alimlerinden İmam Ebû Yûsuf, İmam Muhammed ve Esed b. Amr vb. alimlerden fikıh ve hadis dersleri ald1. ${ }^{61}$ Ebû Yûsuf da ondan Muvatta'y1 dinledi. 62

Irak'ta Hanefí mezhebine meyleden Esed, Mâlik b. Enes'in vefatı üzerine burada yaşanan hüznü görünce tekrar eski mezhebine sarıldı. Daha sonra Mâlik’in talebelerinden istifade için Mısır'a gitti. Mısır'da başta İbnü'1-Kasım³ gibi Mâlikî imamlarıyla görüştü. İbnü'lKasım'a Ebu Hanife'nin görüşleriyle alakalı Mâlik'in kanaatlerini dinleyerek sorularına tatminkâr cevaplar aldı. Ayrıca İbnül-Kasım'ın mezhep çerçevesindeki içtihatlarını da kaydetti. Bütün bunları el-Esediyye adlı meşhur eserinde topladı. 181/797 yılında Kayrevan'a dönen Esed bu eseri sayesinde meşhur oldu. Ancak ehl-i hadîs taraftarı olan Malikilerden bazıları onu eleştirdiler. Devrin diğer meşhur Mâlikî fakihi Sahnûn, müellifinin engellemesine rağmen el-Esediyye'den bir nüsha elde ederek İbnü'1-Kasım'a tekrar arzetti. İbnü'1-Kasım, daha önce tereddütte olduğu meseleleri tavzih, tashih veya terketmek suretiyle aralarında kendi görüşlerinin yer aldığı çeşitli ilâvelerde bulundu. Ancak Esed, söz konusu ilaveleri kabul etmedi. Onun bu tavrından hoşlanmayan İbnü'l-Kasım'ın el-Esediyye'nin rağbet görmemesi için (bed)duada bulunduğu rivayet edilir. Sahnûn ise tashih edilmiş nüshayı alarak fikıh konularına göre sistematik bir tasnife tâbi tutmuş, esere diğer Mâlikî fakihlerinin görüşlerini eklemiş, muhtemelen asıl metne yöneltilen eleştirileri de göz önüne alarak üzerinde tereddüt edilen hususları çıkarmış ve muhafaza ettiği içtihatları ilâve ettiği bazı hadislerle desteklemiştir. Sahnûn'un şöhretine, el-Müdevvenetül-kübrâ adını verdiği bu yeni eserine büyük rağbet de eklenince el-Esediyye'ye gösterilen ilgi müellifinin ölümünden sonra oldukça azalmıştır. Sahnun'un eserine rağbet artınca Ma1iki mezhebi büyük ilgi görmüş ve Kayrevan Malikilerin merkezi haline gelmiştir ama her iki mezhebi de temsil eden Esed b. Furat'ın Sahnun ile rekabeti, onun Hanefi mezhebine meylini artırmıştır.

Esed b. Furât, İbnü'l-Kasım ile yaşanan bu hadiseler sebebiyle onun vefatından sonra Ebû Hanife'nin eserlerini rivayet etmeye başladı. Bazen bu mezhebe ait içtihatları İmam Mâlik’in içtihatlarına tercih ettiği de olurdu. Böylece o, taassup yapmaksızın Hanefi ve Maliki mezheplerini İspanya sınırlarına kadar tüm Kuzey Afrika'da neşretmek için çalışmıştır. ${ }^{64}$

\section{1. 1. Esed b. Furat'ın Kayrevân ve Kuzey Afrika Kadılığı}

Misır'dan dönen Esed, Kayrevân'da kendisini ilmi faaliyetlere verdi, pek çok talebe yetiştirdi. Şöhreti her tarafa yayıldı. Kuzey Afrika'da dönemin en büyük âlimi oldu. Bu ilmî konumu ve etkisinden dolayı 203 veya 204 senesinde 58 yassinda iken Ziyadetullah b. İbrahim tarafından başkent Kayrevân ve Kuzey Afrika genel kadılığı ile görevlendirildi. ${ }^{65}$ Esed, bu

\footnotetext{
60 Temîmî, Tabakâtü ulemâi İfrîkıye, 83.

${ }^{61}$ Kevserî, Muhammed Zahid, Bulûğu't-eman fi sireti'l-İmam Muhammed b. el-Hasan, eş-Şeybani, (Misır: Mektebetü'l-Ezheriyye, 1998), 16.; Temîmî, Tabakâtü 'ulemầi İfrîkıyye, 82.

${ }^{6}$ Ebu Abdullah Muhammed b. Haris Huşeni, (ö.361), Kudatu Kurtuba ve Tarihi Iffrikıyye, (Kahira: Mektebetü'lHancî, 1994), 63.

63 Tam adı Abdurahman b. Kasımdır. İmam Malik’ten ders almıs, İmam Malik onu fakih olarak vasfetmiștir. Sahnun, Müdevvene'yi ondan istinsah etmiştir. 191/806 da vefat etmiştir. Bk. Hafız Ebû Abdillâh Şemsüddîn Muhammed b. Ahmed b. Osmân ez- Zehebî, (ö. 748/1348) El-ïber fi Haber min Ğtber. 4 cilt, (Beyrut: Darü'l-Kütübü'l-İlmiyye. ts), 1: 238. (Zehebi İbn Kasım'ın 191 de vefat ettiğini yazar).

${ }^{64}$ Cengiz Kallek," Esed b. Furat," Türkiye Diyanet Vakfi İslam Ansiklopedisi, (Ankara: TDV yay, 1995), 11: 366.

${ }^{65}$ Hüseyin Mu’nis, Me'âlimu târihi'l-Magrib ve'l-Endülüs (Kahire: Dârü'r-reşâd, 2004), 101.
} 
göreve getirildiğinde Hanefi mezhebine mensup Ebu Muhriz b. Abdullah el-Kinânî de ${ }^{66}$ (ö. 214/829) kadı idi. O zamana kadar bir bölgede iki kadının aynı anda görevlendirildiği görülmemişti. ${ }^{67}$

Sicilya'nın fethinde orduya emîr ve kadı tayin edilen Esed, bu iki görevi şahsında birleştiren yani "kad1-asker(kazasker) olan ilk İfrîkıyeli kabul edilir. Birçok yeri fetheden Esed bir yıla yakın muhasara ettiği Sicilya'daki Sirakusa (Syracusa) önlerinde 213/828) tarihinde şehit düştü. 68

Zahidü'l-Kevserî, İmam Muhammed'e dair yazdığı eserinin önce mukaddimesinde ve ilerleyen sayfalarda Esed'in Hanefi eserlerden etkilenmesi konusunda şunları söyler: "Bu gün elimizdeki ilk yazması Esed'e ait olan daha sonra Sahnun tarafından yazılan Müdevvene ve İmam Şafiî̀nin El-Ümm gibi mezheplerin temel kitaplarının hepsi İmam Muhammed'in kitaplarının 1șığında te'lif edilmiştir."69 "Eğer Esed b. Furat İmam Muhammed'in kitaplarını görmeseydi, bu kitaplarda öğrendiği şeylerin karşılığının Maliki fikhında ne olduğunu cevaplamasını istediği zaman, hocası Abdurrahman b. Kasım'ın ona sorduğu sorulara Irak fikhından öğrendiklerinin dişında başka bir şeyle cevap veremezdi. Dolayısıyla, Sahnun'un Müdevvene'sinin temelini oluşturan bilgiler, aslında Esed b. Furat'in İmam Muhammed'den öğrendikleri ışığında tamamladığı bilgilerdir.”70

\section{2. Ebu Muhriz Muhammed b. Abdullah el-Mütekaddim}

Kaynaklarda "Ebu Muhriz" künyeli baba ve oğul olmak üzere iki kişiden önce kadı olana "el-mütekaddim” denilmiştir. Baba Ebu Muhriz İmam Malik ile görüşmesine ve ondan hadis rivayet etmiş olmasına rağmen, o yıllarda günümüzdeki kadar mezhep taraftarlığı ve taassubu bulunmaması sebebiyle aynı zamanda Hanefi mezhebinde de fakih bir kadı idi. İmam-1 Azam Ebu Hanife'ye talebelik yaptığ1 kesin olan ${ }^{71}$ ve Hanefiliğin Kuzey Afrika ve Endülüs'e girmesinde ve yayılmasında büyük etkisi olan Abdullah b. Ferruh'a ${ }^{72}$ talebelik yapmış biri olarak Ebu Muhriz h.191/806 yılında Kayrevan'da kadılık makamına geçmiștir. Sık1 bir Hanefi olan Ebu Muhriz’in kadılık süresi hakkında kesin bir bilgi bulunmamakla birlikte Esed b. Furat ile aynı zamanda kadılık yaptığı ve vefat ettiği 214/829 yılına kadar önce Kayrevan kadılı̆̆ı, daha sonra Sicilya fethedilip Esed b. Furat vefat edince Sicilya kadılığını da üstlendiği kanaati hasıl olmaktadır. 73

\section{3. Ahmed b. Ebu Muhriz}

Ebu Muhriz'in oğlu Ahmed b. Ebu Muhriz, önce 6 ay süreyle Kayrevan'da daha sonra ise 220/835 yılında dokuz ay sürecek olan Sicilya kadılığını ${ }^{74}$ Hanefi mezhebi müntesibi olarak yaptığı kaydedilir. Vefat tarihi h.221/836 dir.

\section{4. İ̉nn Ebi'1-Cevâd}

Ağlebî hükümdarı Muhammed b. Ağleb (h.226/841) zamanında görev yaptığı ve 232/847 yılında kadılıktan azledildiği kaydedildiği için ${ }^{75}$ Ebu Muhriz'lerden sonra kadılık yaptığ1 söylenebilir. ${ }^{76}$ Maliki mezhebine mensup Sahnûn'un hayatından bahsedilirken, onun Vehb isimli sütkardeşinin cenaze namazını, Kayrevan kadısı ve aynı zamanda Esed b. Furât'ın

\footnotetext{
${ }^{66}$ Kettanî şeklinde de okunur. Vefat tarihine rastlanmamaktadır. Bk. Temîmî, Tabakâtü ulemâi İfrîkıyye, 84.

${ }^{67}$ Ebu Zeyd Abdurrahman b. Muhammed ed-Debbâğ, (ö.696), Meâlim'ül-İmân fì ma'rifeti ehli'l-Kayrevân, thk. Tenûhî, Abdurrahman b. Muhammed (ö.839), 3 cilt, (M1sır: Mektebetü'l-hancî, 1968), 1: 19.

68 Kallek," Esed b. Furat," 11: 368; Temîmî, Tabakâtü ulemâi İfrîkıyye ve Tûnis, nşr. Ali eş-Şâbbî-N. Hasan elYâfî, (Tunus: Daru'l-Kütübü'l-Lübnanî, 1985), 81-83.

${ }^{69}$ Kevserî, , Bülûğu'l-Emânî fì Sîreti'l- İmam Muhammed, 3.

70 Kevserî, Bülûğu'l-Emânî fì Sîreti'l-İmam Muhammed, 18.

${ }^{71}$ Muhammed b. Ahmed et- Temîmî, Kitâbu Tabakâti Ulemâ-i İfrîkiye, (Beyrut: y.y., ts.), 1: 34.

72 Endülüs'te (115/733) yılında doğdu. İlim için önce Kayrevan'a geldiği buradaki tahsilden sonra ilerlemiş yaşına rağmen Doğu'ya yeniden 145/763 ilmi yolculuğa çıktığı kaydedilir ki, bu tarih Ebu Hanife'nin vefatından beş sene öncesidir. Döndükten sonra Kayrevan'da Abdullah b. Ferruh fahri kadılık yapmış ve h.176/792'da vefat etmiștir. Bk. Halid Ebu Hind, el-Mezhebü'l-Hanefì ve Ricâlühü bi bilâdi'l-Mağribi'l-İslâmî, (Tunus: Camiatü Seydi bi'l-Abbas, ts), 7: 111.

${ }^{73}$ Muhammed b. Muhammed Salih el-Cudî, (ö.m.1943), Tarîhu Kudâti'l-Kayrevân, (Tunus: Matbaatü Vefa, 2004), 62.

${ }^{74}$ Ebu'l-Abbas Ahmed b. Muhammed el-Uzzârî,(ö.h.712), el-Beyânu'l-mağrib fi ihtisâri ahbâri'l-Endelüs ve'lMağrib, 4 cilt, (Tunus: Daru'l-garbi'l-islamî,2013), 1:146.

75 Uzzârî, el-Beyânu'l-mağrib, 1:150

${ }^{76}$ Muhammed b. Haris Huşenî,(ö.361), Kitabu Tabakati Ulema-i İfrikıye, (Beyrut: Dâru'1-Kitâbi'1-Lübnânî, ts.), 83.
} 
damadı da olan Mu'tezilî-Hanefî İbn Ebü'1-Cevâd k1ldırdığı için protesto ettiğine dair bilgilerden ${ }^{77}$ onun ciddi bir Hanefi mezhebi mensubu olduğu anlassılmaktadır.

\section{5. Süleyman b. İmran}

Hicri 183/799 tarihinde doğmuş 270/883 tarihinde vefat etmiștir. Sahnun zamanında başlayan çift kadı uygulamasına binaen, Abdullah b. Ahmed b. Talip ile aynı zamanda kadılık yapan Süleyman, Sahnun'un vefat yılı olan 240/855 da kadı olur ve 270/883 y1lına kadar devam eder. Sahnun Maliki, diğer kadılar ise Hanefi mezhebine göre hüküm verirlerdi. ${ }^{78}$ Önceleri Iraklıların mezhebine (Sevrî, Evzaî ve Hanefi) mensup iken, Sahnun'un israrları üzerine önce Maliki bölge olan Bacce kadılığı da yapar. Bu, onun Maliki mezhebine de hakim olduğunu gösterir. Siyasi nedenlerle dönüşümlü kadılık yaptıkları kaydedilir. ${ }^{79}$

\section{6. Abdullah b. Abdun}

Ağlebî emiri II. İbrahim b. Ahmed zamanında (875-900) Hanefi mezhebine mensup kadı olan Ebu'l-Abbas İbn Abdun ${ }^{80}$ 275/888 tarihinde kadı olmuştur. Üç seneye yakın kadılık yapmıştır. ${ }^{81}$ Uygulamadaki bazı hataları sebebiyle kısa süreli kadılık yapmıştır.

\section{7. Abdullah b. Harun es-Sûdanî}

Tunus şehrinin kadısı iken II. İbrahim tarafından İbn Abdun'dan sonra Kayrevan kadısı yapılmış ve iki yıl yani 891-893 yılları arasında bu görevde kaldığı kaydedilir. ${ }^{82}$

\section{8. Hamas b. Mervan}

Mutezilî görüşlere sahip olmakla birlikte zühd sahibi olduğu, fetva vermek için yanında daima dört tane fakih bulundurduğu ve onun zamanında adaletin her alanda hissedildiği kaydedilen Hamas b. Mervan, 222/836-302/915 yılları arası yaşamıştır. İbn Ceymal'den önce 290/903-294/907 tarihlerinde dört yıl süreyle kadılık yapmıştır. ${ }^{83}$

\section{9. Muhammed b. Ahmed İbn Ce(y)mal ve Diğer Kâdîlar}

Hayatı hakkında fazla bilgi bulunmamakla birlikte hicri X. yy.ın sonlarına doğru yani Ağlebîlerin son emiri Ziyadetullah b. Abdullah (903-909. yıllar) zamanında görev yaptığ1 belirtilen Hanefi fakih/kadılardan birisidir. Fakat, ilmi yetersizliği sebebiyle azledilen İbn $\mathbf{C e}(\mathbf{y}) \mathbf{m a l}^{\text {'in }}{ }^{84}$ ardından kadılık görevine getirilen İbrahim b. Haşşab'in ${ }^{85}$ da yine bilgisizliği ve yetersizliği üzerine kadılıktan kaçması belki de Hanefiliğin Sicilya'daki resmi mezhep statüsünü kaybetmesine zemin hazırlamıştır kanaatindeyiz.

Bu kadılardan başka h. ilk üç yüz yılda görev yapan ve görev süreleri bildirilmeyen bazı kadılar da vardır. Ağlebilerin son zamanlarında kadılık yapanların sürelerinin de azalmaya başladığ görülür. Önceleri Abdullah b. Abdun'un katibi iken daha sonra kadılık da yapan Ebu Affal b. Cercer ${ }^{86}$ de bu kadılardan biridir. Bu bilgiden hareketle ilk üçyüz yıl Kayrevan ve Sicilya'da hala Hanefi kadıların bulunduğu anlaşılabilir. Yine, Ebu'1-Kasım et-Tûri 87 ile Hanefi alimlerden Abu'l-Abbas b. Zurzur, Maliki ve Hanefi mezhebini mukayeseli bilecek kadar bilgili idi. Onun, "İmam Ebu Hanife ile İmam Malik ikisi birlikte bir elbise giydirseler ya da dikseler, onu hangisinin diktiği bilinmezdi”, dediği nakledilir. ${ }^{88} \mathrm{Bu}$ ifadeden onun her iki imamın da bilgi bakımından eşit derecede alim olduklarını takdir edebilecek derecede mezhebe hakim olduğunu ya da her iki mezhep arasında çok büyük fark olmadığını belirtmek için böyle bir cümle kurduğu söylenebilir. Ağlebilerin son dönemlerindeki zayıflama sebebiyle kısa süreli kadılığa atanan ve bu sebeple de görev yaptıkları zaman dilimi tespit edilemeyen

\footnotetext{
77 Temîmî, Tabakâtü ulemâi İfrîkıyye, 236.

78 http:/ / www.mawsouaa.tn/wiki / الدذبـ الحنفي_بالبلاد التونسبة

79 Cûdî, Tarihu Kudati Kayrevan, 80; Huşeni, Kitabu Tabakati Ulema-i Ifrikıye, 180.

${ }^{80}$ Huşenî, Kitabu Tabakati Ulema-i İfrikıye, 187.

81 Cûdî, Tarihu Kudati Kayrevan, 85;

82 Cûdî, Tarihu Kudati Kayrevan, 85;

83 Cûdî, Tarihu Kudati Kayrevan, 93.Temîmî, Kitabu Tabakati Ulema-i Ífrikıye, 160.

${ }^{84}$ Bazı nüshalarda Cemal, bazılarında Ceymal şeklinde yazılmıştır. Bk. Huşenî, Kitabu Tabakati Ulema-i Ifrikıye, 196; Cûdî, Tarihu Kudati Kayrevan, 96.

${ }^{85}$ Hayatı hakkında bilgi yoktur. Bk. Cûdî, Tarihu Kudati Kayrevan, 96.

${ }^{86}$ Hussenî, Kitabu Tabakati Ulema-i İfrikıye, 192.

${ }^{87}$ Huşenî, Kitabu Tabakati Ulema-i İfrikıye, 164.

88 إن مالكا و ابا حنيفة لو سؤلا أن يحوكا ثوبا او يخيطاه ما عرفاه Bk. Huşenî, Kitabu Tabakati Ulema-i Ifrikıye, 190.
} 
bazı Hanefi Kayrevan kadıları arasında Ebu Bekr İbn Selman ${ }^{89}$ da sayılabilir. Sonuçta, Ağlebîler güçlü iken Hanefi mezhebi de güçlü, onların gücü zayıflayınca Hanefi mezhebinin varlığı da zayıflamış gibi anlaşılmaktadır.

\section{Sicilya'da Hanefiliğin Kabul Görme Sebepleri}

İslam tarihi kaynakları genellikle Mağrib’te Malikiliğin yaygın olduğunu belirtirler. Aslında bu durum miladi XI. ve XII. asırlardan sonraki durumu ifade etmektedir. Sicilya coğrafi bakımdan Mağrib'e dahil edildiği için orada Hanefiliğin varlığı unutturulmuş ve sanki Misır'dan ötesinin tamamının hicri II. asırdan bu yana Maliki mezhebine müntesip olduğu intibaı yayılmıștır. Halbuki Sicilya'da, bölgede yaygın olan Maliki mezhebi yerine Hanefi mezhebinin yaygınlaşmasının ve bu adada uzun yıllar icrada bulunması ile daha sonra Maliki mezhebinin bu coğrafyaya hakim olma sebepleri önemlidir. Tam da burada "coğrafyanın fikha tesiri” bağlamında bazı araștırmacıların tespitler yaptıkları görülür. Onlara göre Sicilya, etrafı denizlerle çevrili olduğu için ılıman bir iklime sahiptir, verimli topraklar bulunmaktadır ve bu topraklarda bolca üzüm yetiştirilmektedir. Üzüm ise farklı amaçlarla kullanılabilecek bir mahsuldür. Bu sebeple Hanefilik Sicilya iklimine uygundur. 90

\section{1. Coğrafi ve Kültürel Sebepler}

Toplumda yerleşik örf ve adetlerin, sosyo-kültürel ve coğrafi şartların o toplumun bir fikıh mezhebi tercihinde etkili olması normaldir. Mağrib’tekilerin Hicaz fikhını kendi hayat tarzlarına daha uygun bulmaları gibi, ${ }^{91}$ Horasan coğrafyasında yaşayanların da Hanefiliği kendi örflerine uygun bulmaları muhtemeldir.

Kur'an'da zikredilen peygamberlerin Mekke merkez olmak üzere yaklaşık bin km'lik bir çaptaki coğrafyada yaşayanlar oldukları görülür. Mezheplerin kendilerine zemin oluşturmalarında da bu coğrafya etkili olmuş, Hicaz, Irak, Yemen ve Şam bölgeleri hep önde olmuşlardır. Fetih hareketlerine bakıldığında Irak'in Horasan yolu üzerinde, Şam diyarının Anadolu taraflarında, Hicaz'ın Yemen tarafında olmaları, coğrafyanın fikha etkisi bağlamında ele alınabilir. Dolayısıyla, en yakın coğrafyadaki mezhep imamı o bölgede taklid edilir hale gelmiştir. Mağriblilerin Malikiliği tercih etmesinin hac yolu üzerinde bulunması olduğu kaydedilir. ${ }^{92}$ Makdisî de Mağrib'te ilk mezhebin Evzaîlik olmasına rağmen uzun süre bu coğrafyada kalamamasını Şam'ın o günkü konumu itibariyle hac yolu üzerinde bulunmayışına bağlar. ${ }^{93}$

Hanefiliğin Sicilya'ya girmesini ve orada istikrar bulmasını, adadaki yerleşik örf ile sosyo-kültürel ve coğrafi şartlara bağlayan bazı araştırmacılar Hanefi mezhebinin "hamr"1 haram sayarken, ondan biraz daha farklı özelliklere sahip "nebiz" isimli içeceğe müsaade etmesine bağlarlar. ${ }^{94}$ Şöyle ki: Hanefi ekolüne göre üzüm ve hurmadan elde edilen sarhoş edici nebizin sarhoş edecek kadar içildiğinde haram olduğu, daha az içildiğinde ise haram olmadığı görüşünü benimsemişlerdir. Bunun hoşaf ve şerbet olduğu anlaşılmaktadır. Ancak, üzüm suyu, bekletildiği zaman kabarıp çoğalarak köpük atarsa, şarap haline gelmiş olur. Bunun çoğunun ve azının haramlığı hususunda ümmetin icma'1 vardır. Hanefiler üzümün dişındakilerden elde edilen nebizi, hamr (şarap) adıyla isimlendirmemektedir. Onlara göre, hurma ve kuru üzümden elde edilen zebib pişirilmemiş/kaynatılmamış halde iken sarhoş edici özellikte ise, azı da çoğu da haramdır. Ancak şarap olarak isimlendirilmez ve az da olsa pişirildiğinde sarhoş etmeyecek kadar içilirsese helaldır. Fakat, üzüm suyu sarhoş edici bir hal almışsa, üçte biri kalana kadar pişirilirse, yenebilir. Ancak, şaraplaşan üzüm suyunun pişirilse bile haramlığının kalkmayacağı tartışmasızdır. ${ }^{95}$

Şarap dışında kalan ve kuru üzüm, kuru hurma, arpa, darı, bal gibi maddelerden elde edilen ve farklı isimlerle anılan içeceklerin kaynamışlığına, kaynama miktarına, köpürme ve keskinleşme safhalarına, sade veya karışık olmasına, hatta üretiminde kullanılan kap ve alete ve üretim usulüne göre farklı dinî hükümler verilmekle birlikte fakihlerin bu tür içeceklerin sarhoş edicilik vasfi varsa haram sayılmaları gerektiği, Ebû Hanîfe ve İmam Ebû Yûsuf'un ise

\footnotetext{
${ }^{89}$ Huşenî, Kitabu Tabakati Ulema-i Ifrikıye, 226.

90 Chiarelli, A History of Moslim Sicily, 290.

91 İbn Haldun, Kitabu'l-ïber, 3: 1054.

92 İbn Haldun, Kitabu'l-íber, 3: 1055.

93 Makdisî, Ahsenü't-tekasim, 144.

${ }_{94}$ Chiarelli, A History of Moslim Sicily, 291.

${ }^{95}$ Mustafa Baktır, "İçki”, Türkiye Diyanet Vakfı İslam Ansiklopedisi, (TDV Ankara, 1998), 21: 458.
} 
bu gruptaki bazı içeceklerin sarhoşluk vermeyen miktarının içilmesini haram saymadığı veya had ile cezalandırmadığı bilinmektedir. Hanefî fakihlerinin şarap dışındaki içki ve içecekler için genel bir ilke benimsemek yerine her içki türünü yukarıda belirtilen açılardan ayrı ayrı ele alıp niteliklerine göre dinî hükmünü belirlediğini ve bu içeceklerin hangi safhalarda haramlık hükmünü alacağı, necis veya mütekavvim mal sayılıp sayılmayacağı, hangi durumlarda kendilerinden yararlanılabileceği gibi ayrıntılarda da aralarında görüş farklılığı olduğunu belirtmek gerekir. ${ }^{96}$

Tercihe şayan olan görüş cumhurun görüşü ise de Hanefilerin görüşü, Sicilya'da üzüm bağlarının çokluğu ve onlara nebiz üretmelerini yasaklamaması nedeniyle revaç bulmuş bu da Hanefiliğin orada uzun süre kalmasının sebeplerinden birini teşkil etmiştir.

Yine, Sicilya'da halk arasında zuhur eden bir ayaklanmayı bastırmak ve halkın sorunlarını yerinde çözmek üzere II. İbrahim (ö.261), Heysem b. Süleyman(ö.275/888) ${ }^{97}$ ve Kasım b. Ebu Menhel ${ }^{98}$ isimli iki tane Hanefi kadıyı oraya göndermiş, onlar da halkın ileri gelenlerine sayg1 göstermişler, böylece huzursuzluk sakinleştirilmişti. Hanefi kadıların bu zarif/latif davranışı bölge halkından hüsn-i kabul görmüş ve Hanefi mezhebinin intişarına katkı sağlamıştır. ${ }^{99}$

Son yıllarda Müslümanlar döneminde Sicilya kültürü ve Sicilya'da uygulanan Hanefi fikhının Sicilya hukukuna katkıları ve buradan Batı hukukuna tesirlerini inceleyen araştırmalar yapılmıştır. Bunlardan birisi de John Makdisî isimli bir araştırmacının hazırladığı çalışmada, günümüz İngiliz hukukundaki akdin kuruluşu ve akdin hükümleri gibi usul hukukuna dair konuların Sicilya ve Endülüs'teki Hanefilik üzerinden İngiltere hukukuna geçtiğini, daha önceleri bu konuların Normand hukukunda olmadığını bildirir. 100 Mesela, Bat1 hukuk literatüründe kullanılan judge ${ }^{101}$ (okunuşu qadg1-kâd1), jura(şura, jüri), actions(asıl okunuşu akdıya) eylemler/olaylar, contrackt (karş1lıkl1 akit), noeud,(akid), credi/card(karz), usure(ușur ve vergi, faiz), fee(fey'/vergi), invoice(infak-nakil-satış belgesi), science(kıyas), agreement(ukırru veya ekrimî) kabul etme gibi aslı Arapça ya da Arapçadan etkilenmiş literatür bulunmaktadır. ${ }^{102}$

Nitekim, Hristiyan Normandlar 1091 yılında adaya tamamen hâkim olunca ilk olarak siyasi kontrolü sağlamışlar, fakat Müslümanlardan ve özellikle Hanefi hukukundan istifade etmeye devam etmişler onlara hoşgörülü yaklaşıp her konuda faydalanmışlardır. Hatta, Bizans'a karşı yapılan savaşta Müslüman askerler Normandların yanında yer almıştır. Adanın yeni sahipleri, tecrübeli Müslüman devlet adamlarını istihdam edip devlet işlerinde şura, teknik işler, yönetim usulleri, divanı, askeri usulleri, kısaca İslam yönetim modelini, tabii olarak Hanefi fikhını uygulamaya devam etmişlerdir. Kraliyet sarayında aralarında Arapçanın da bulunduğu üç farklı dille Latince "Duana de Secretis", Yunanca "Mega Sekreton" ve Arapça "Divân-1 tahkik e'l-ma'mûr" yazdırmışlar, Endülüs'te olduğu gibi kin ve nefrete kapilarak Arapçayı hemen terk etmemişlerdir. ${ }^{103}$ Dolayısıyla, Sicilya'da Ağlebî iktidarının 909 da sona erdiği dikkate alındığında, adada Hanefiliğin etkisinin en az 150 yıl daha devam ettiği söylenebilir.

Ayrıca, 1215 tarihinde İngiltere'de kralın bazı haklarından vazgeçerek, kanun önünde kral da dahil olmak üzere herkesin eşit olduğunu ilan eden ve ilk insan hakları belgesi mahiyetindeki "Büyük şart" olarak tercüme edilen "Magna Carta/Charta"'nın da Sicilya ve Endülüs'teki İslam Hukuku uygulamaları ve 1stılahından etkilendiği belirtilir. ${ }^{104}$ Zaidan Ali Jassem ise "İngilizce ve Avrupa Dillerindeki Demokrasi Terimlerinin Kökeni Üzerine Radikal

\footnotetext{
96 Baktır, "İçki”, 21: 458.

97 Huşenî, Kitabu Tabakati Ulema-i Ífrîkıye, 192.

98 Huşenî, Kitabu Tabakati Ulema-i İfrîkıye, 191.

99 Chiarelli, A History of Moslim Sicily, 293.

100 Borham, Atallah, Tatbîku'ş-Şerîâti'l-İslamiye fî Sıkılya'l-İslamiyye ve'n-Normandiye, (Misır: İskenderiye Hukuk Fak. Yayını, ts.), 7. (Geremy Johns, Arabic Administration in Norman Sicily: The Royal Diwan, Cambridge Studies in Islamic Civilization, 2002) den naklen, 11.

101 İspanyolca'da j harfi, duruma göre $\mathrm{k}$, h ve Arapçadaki noktalı h ve kaf harfi için kullanılmaktadır.

102 http://www.diwanalarabia.com/Intro.aspx (Erişim: 10.04.2019).

103 Azîz Ahmed, Târîhu Sıkılyeti’l-İslâmiyye, trc. Emîn Tevfîk et-Tayyibî, (Tunus, y,y., 1980), 70.

104 Haluk Songur, Human Rights and Islam: An Attempt To Compare The Farewell Address Of The Prophet And The Magna Carta, Süleyman Demirel Ün. İlahiyat Fakültesi Dergisi 2/ 19, (Isparta 2007). https://www.cambridge.org/core/books/magna-carta-religion-and-the-rule-of-law/quranic-magna-carta-onthe-origins-of-the-rule-of-law-in-islam/CC7FC75784D174061DF93C7A1BA408EA
} 
Bir Dil Teori Kuramı"105 mealinde tercüme edilebilecek İngilizce makalesinde 'magna carta' ifadesinde Arapçanın, yani İslam hukuku kavramlarının etkisini açıklamaya çalışır. Bu makale ile 103. dipnottaki internet adresinde bazı Arapça kelimelerin harfleri yer değiştirilerek İngilizceye geçtiği izah edilmekte ve bazı tahminlerle "magna'nın "mecîd" yani büyük, değerli (great) manasına geldiği, 'carta' ise Arapçadaki cerîde/gazete/belge ya da kırtâs/kağıt manasında kullanıldığı, charta şeklinde yazılırsa "şarta" kelimesi gibi bir izlenim oluşturduğu izah edilmektedir. Buna göre telaffuz edildiği gibi yazmayı denersek "mecîd carîde" ya da mısır sîvesiyle "megîd carta, "mecîd şarta' tamlamalarının manasının "değerli sözleşme/belge" olduğu yorumları yapılmakta106 ve zamanla İngilizce aksana "magna carta/charta" şeklinde aktarılarak dilden dile aktarılmıştır. En azından 'carta/charta' kısmının Arapça olduğu ve bunun da İslam medeniyetinden alındığını söylemek teoriden ziyade bir vakıadır denebilir. Nitekim, İspanya'daki seyahatlerimizde İngilizceyi yazıldığ gibi okursanız bu İspanyolca olur. O kelimelerin de belli oranının aslı Arapçadır denilmiştir. Carta kelimesinin sözlükteki karş1lığı zaten "büyük şart” olarak tercüme edilmektedir. ${ }^{107}$

Her ne kadar bazı yazarlar Sicilya'da Ağlebîlerin yıkılıp yerine Fatımîlerin geçmesinden sonra Hanefiliğin yavaş yavaş terkedilmeye başladığını yazsalar da kanaatimizce bu doğru değildir. Miladi 909 yılında Fatımîlerin iktidara gelmesiyle hemen Hanefilik sona ermemiş, yine uzun yıllar Sicilya'da kalmaya devam etmiştir. ${ }^{108}$ Belki, Hanefilik resmi mezhep olmaktan çıkmışsa da bu mezhebin oluşturduğu kültür devam etmiş, yazılan eserlerde bu mezhebin görüşleri yer bulmaya devam etmiştir demek daha doğru olur.

Nitekim, Ağlebilerin 909 yılında iktidardan uzaklaşmalarından yaklaşık yüz sene sonra yani miladi 999/1000 yılında vefat eden Makdisî, kendi yaşadığı dönemi anlatırken, Sicilya halkının çoğunluğunun hala Hanefî olduğundan bahsetmesi, ${ }^{109}$ Hanefiliğin Fatımîlerin iktidara gelmesiyle sona ermediğini gösterir.

\section{Sonuc}

Hanefi mezhebinin Mağrib ve Sicilya'daki serencamının araştırılmaya çalış1ldığı bu araștırma, iddia edildiği gibi Hanefi mezhebinin ömrünün bu coğrafyada çok az olmadığını ve az bilinen bir mezhep olmadığını göstermektedir. Hanefilik Irak'ta ne zaman yayılmaya ve kök salmaya başlamışsa, aynı vakitte Akdeniz'in Afrika ve Endülüs yakasından oluşan İfrîkıye'de de (bilâd-1 mağrib) taraftar bulmaya başlamış, özellikle kadılar aracilığıyla yüzyıllar boyunca resmî mezhep olarak yerini korumuştur.

Mezheplerin ömürleri de insan ömürlerine benzemektedir. İktidarda olanlar hangi mezhebi savunmuşlarsa o mezhep revaç bulmuştur. Sicilya'da da valilerin atadığı Hanefi kâdîlar işbaşında iken bu mezhep hep belirleyici olmuştur.

Hanefi mezhebinin hayatın içinden süzülerek gelmesi, nakil ile akılı belli kıstaslar dahilinde buluşturması ve dinamik yapısı sebebiyle tüm çağlarda hüsn-i kabul görmüştür. Öyle ki, sadece icra makamında kalmamıs, diğer din mensuplarının da dikkatini çekmiş, onlara yön vermiş ve kendisine batı hukukunda yer bulmuştur.

Sicilya'da y1llarca Hanefiliğin takip edilmesinin sebeplerinden belki de en kuvvetlisi, Sicilya'y1 fetheden komutan olan Esed b. Furat'in aynı zamanda Hanefi mezhebine mensup bir kâdî olmasıdır. Esed'in Sicilya'yı fetih esnasında vefat etmesi, daha sonra gelen nesiller için bir vefa borcu gibi algılanmış ve bu adaya her zaman Hanefi kadıların atanması için vesile olmuştur kanaatindeyiz. Her ne kadar Kâdî Esed Malikiliğe hakim olsa da onun daha çok Hanefi mezhebine meyilli olduğu belirtilir. Çünkü o, İmam Malik'in Muvatta'inın tekrar gözden geçirilmiş hali olan "el-Esediyye" isimli eseri hocası İbnü'l-Kasım'a takdim etmiş, ardından Sahnun bu eseri yeniden dizayn ederek "konularına göre tedvin edilmiş" manasında "el-Müdevvene" şeklinde isimlendirmesinin ardından, İbnül-Kasım bu eseri daha çok beğenmesi üzerine Esed'in hocasına darıldığı, bu dargınlık üzerine de hocasının Esed'e

\footnotetext{
105 Zaidan Ali Jassem, The Arabic origins of English and indo-European "Democratic Terms": A Radical Linguistic Theory Approach, VEDA'S - Journal Of English Language and Literature (JOELL), (2015), 2: 38.

106 Zaidan Ali Jassem, The Arabic Origins of English and Indo-European "Legal Terms": A Radical Linguistic Theory Approach, International Journal of Applied Linguistics and Translation 1/3: 35-49 (2015).

$107 \mathrm{https://translate.google.com/ \# view=home \& op=translate \& sl=auto \& tl=tr \& text=carta} \mathrm{(Erişim:} \mathrm{15.04.2019)} \mathrm{Bu}$ en pratik çeviri sayfasına carta yazılınca, kağıt ve belge, charta yazılınca ise şart ve tüzük manaları çıkmaktadır. 108 Borham, Tatbîku'ş-Şerîâti'l-İslamiye fî Sıkılya'l-İslamiyye 7.

109 Makdisî, Ahsenü't-Tekâsîm, 238.
} 
beddua ettiği hususlar birlikte değerlendirildiğinde, Esed’in kendisinin de artık bu esere sahip çıkmadığı, onun yerine Hanefi mezhebinin görüş ve içtihatlarına daha çok meylettiği, bu sebeple de onun önce Maliki, vefatına kadar da Hanefi olduğunu söylemek mümkündür.

Bu duygusal bilgilerin yanında, Hanefiliğin Sicilya'da rağbet görmesinin ardında adada yaşayan çoğunluğu ilgilendirmesi sebebiyle "hamr" ile "nebiz" arasında Hanefilerce farklı ve kolaylaştırıcı içtihatların bulunması, adı geçen mezhebin diğer ilkelerinin de kolayca kabul görmesine etki ettiği söylenebilir.

Bu etki sadece Müslüman halk nezdinde kalmayıp bölgedeki diğer din mensuplarınca da hayretle izlenmiş ve bugünkü "usul hukuku"nun altyapısını Hanefi mezhebinden esinlenerek oluşturmuşlardır. Bu mezhebin ilke ve içtihatlarından Hristiyanların bile kolayca istifade etmesi ve rağbet göstermesi, Müslümanların da mezheplerine sıkı sıkıya bağlanmalarına, böylece uzun yıllar adada yaşamasına zemin hazırlamıştır.

Mısır'in fethiyle Doğu'daki müctehidlerin görüşlerinin Kuzey Afrika'ya transferi kolaylaşmış, böylece Endülüs ve Sicilya'ya kadar ulaşmıştır. Bir yerde birden fazla insan varsa orada hukuk, adalet, yani kâdi ve mahkemeye ihtiyaç vardır. Bu sebeple de Müslümanların fethettiği hiçbir coğrafya müftî, kâdî ve imamsız bırakılmamış, tayin edilen kadıların mensup olduğu mezhep haliyle halkın mezhep mensubiyetinde etkili olmuştur.

\section{Kaynaklar}

Abbas, İhsan. el-Arabu fî Sikılliyye. Beyrut: Daru's-sekâfe. 1975.

Abduh, Muhammed. Muhaveratu'l-muslih ve'l-mukallid. Trc. Gerçek İslamda Birlik adıyla Hayrettin Karaman. Ankara: DİB Yay, 1996.

Abdülbâki, Muhammed Fuad. el-Mu'cemu'l-Müfehres li elfazi'l-Kur'ani'l-Azîm. Beyrut: Dârü'1Ma'rife. 1945.

Aslan, Nasi. İslam Hukukunda Yargılama Etiği ve İlkeleri. Adana: Seçkin Yayıncılık. 2014.

Atar, Fahrettin. F1kıh Usûlü. 8. Baskı. İstanbul: İFAV Yay. 2010.

Azimli, Mehmet. "Sicilya'daki İslâm Medeniyetinin Avrupa'ya Etkileri." İstem 16, Konya: 2010.

Baktır, Mustafa. "İçki”. Türkiye Diyanet Vakfı İslam Ansiklopedisi. Ankara: TDV. 1998.

Borham, Atallah. Tatbîku'ş-Şerîâti'l-İslamiye fî Sıkılya'l-İslamiyye ve'n-Normandiye.

İskenderiye Hukuk Fak. Yayını. (Geremy Johns, Arabic Administration in Norman

Sicily: The Royal Diwan, Cambridge Studies in Islamic Civilization, 2002) den naklen.

Chiarelli, C, Leonard. A History of Moslım Sicily, MidseaBooks: 2011.

Cudî, Muhammed b. Muhammed Salih(ö.m.1943), Tarîhu Kudâti'l- Kayrevân, Tunus: Matbaatü Vefa. 2004.

Damad, Şeyhzade Abdurrahman b. Şeyh Muhammed. Mecmeu'l-Enhur. İstanbul: Matbaa-i Amire. 1308.

Debbâğ, Ebu Zeyd Abdurrahman b. Muhammed(696), Meâlim'ül-İmân fî ma'rifeti ehli'1-

Kayrevân, Thk. Tenûhî, Abdurrahman b. Muhammed (839/1435), 3 cilt, Misır: Mektebetülhancî, 1968.

Ebu Hind, Halid. el-Mezhebü'l-Hanefî ve Ricâlühü bi bilâdi'l-Mağribi'l-İslâmî. Tunus: Camiatu Seydi bi'l-Abbas, ts.

Habergetiren, Ömer Faruk. Fatih Bir Fakih: Ebû Abdullah Esed b. Furât b. Sinan, Hayatı ve F1kıh İlmindeki Yeri. Harran Ün. İlahiyat Fak. Dergisi 27. Şanlıurfa 2012.

Halaçoğlu, Yusuf. XIV-XVII. Yüzyıllarda Osmanlılarda Devlet Teşkilatı ve Sosyal Yapı. Ankara. Türk Tarihi Kurumu. 1996.

Hallaf, Abdülvehhab. İlm-i Usûli'1-F1kh. Misır. Mektebetü'd-da'veti'1-İslâmiyye. 1948.

Hallaf, Abdülvehhab. Hulasatu Tarihi't-teşri'i'l-İslamî. Kuveyt: y.y., ts.

Hitti, Philip K. Arap Tarihinin Mimarları. Trc. Ali Zengin. İstanbul: Risale Yay. 1995.

Hunke, Sigrid. Allahs Sonne über dem Abendland: Unser Arabisches Erbe, Hamburg: Deutsche Verlags-Anstalt.1960.

Huşenî, Muhammed b. Haris. Kitabu Tabakâti Ulema-i İfrîkıye. Beyrut: Dâru'1-Kitâbi'1Lübnânî. ts.

Huşenî, Ebu Abdullah Muhammed b. Haris(361). Kudatu Kurtuba ve Tarihi İfrikiyye, Kahira: Mektebetü'l-Hancî. 1994.

İbn Manzur, Cemaluddin Muhammed b. Mükerrem. (711/1311). Lisanül- Arab. 15 cilt, Beyrut: 1955. 
İbnü'l-Esîr, Ebü'l-Hasan İzzüddîn Alî b. Muhammed (630/1233). Üsdü'l-gâbe fî̀ Ma'rifeti'ssahâbe, 7 cilt. Beyrut: Dâru'l-Kütübi'l-ìlmiyye. 2012.

İbn Hacer, el-Askalânî Ebü'l-Fazl Şihâbüddîn Ahmed b. Ali (ö. 852/1449). el-İsâbe fî

Temyîzi's-sahâbe. thk. Âdil Ahmet Abdülmevcûd, Ali Muhammed Muavviz. 8 cilt, Beyrût: Dâru'l-Kütübi'l-ìlmiyye. 1415/1995.

Jassem, Zaidan Ali. The Arabic origins of English and indo-European "Democratic Terms": A Radical Linguistic Theory Approach. journal of english language and literature (JOELL). (2015).

Kallek, Cengiz. "Esed b. Furat.” Türkiye Diyanet Vakfi İslam Ansiklopedisi.Ankara:TDV. 1995.

Karaman, Hayrettin. Anahatlarıyla İslam Hukuku, 5 cilt, İstanbul: Ensar Neşriyat. 2011.

Karaman, Hayrettin. Dört Risale. İstanbul: İz yayıncilık. 2000.

Karaman, Hayrettin. İslam Hukuk Tarihi. İstanbul: Ensar Yay. 1989.

Kâsânî, Alauddin Ebu Bekr b. Mes'ud. Bedaiu's-Sanai' fi tertibi'ş- Şerai'. 9 cilt. Beyrut: Dâru'1Kütübi'l-İlmiyye. 1988.

Cûdî, Kayrevânî, Muhammed Salih (ö.m.1943). Tarihu Kudati'l-Kayrevân. Tunus: 2004.

Kevserî, Muhammed Zahid b. Hasen. Bülûğu'l-Emânî fî Sîreti'l-İmam Muhammed eş-eybânî. Misır: Mektebetü'1-Ezheriyye, 1998.

Kindî, Ebû Yûsuf Ya'kûb b. İshak (252/866). Kitâbü'1-vülât ve Kitâbü'l-kudât. Beyrut:

Matbaati'l-Yûsûiyyîn. 1908.

Koca, Ferhat. "Mezhep". Türkiye Diyanet Vakf1 İslam Ansiklopedisi. Ankara. TDV. 2004.

Köse, Saffet. İslam Hukukuna Giriş. İstanbul: Kervan Yayınevi. 2012.

Leknevi, Ebü'l-Hasenât Muhammed Abdülhay b. Muhammed (1848-1886). el-Fevầidülbehiyye fî terâcimi'l-Hanefiyye. Kahire: y.y. 1324/1906.

Makdisî, Muhammed b. Ahmet Şemseddin. Ahsenü't-tekâsîm fî ma'rifeti'l-ekalîm. Kahire: 1991.

Mantran, Robert. İslamın Yayılış Tarihi. Trc. İsmet Kayaoğlu. Ankara: A.Ü. İlahiyat Fak. Yayınlar1, 1981.

Medenî, Ahmet Tevfik. el-Müslimûne fî cezîrati Sikilya ve Cenûbi İtaliya. Tunus: Mektebetülİstikame, 1365.

Moreno, Martino Mario. Sicilya'da Müslümanlar. Trc. Abdulhalik Bakır- Aydın Çelik, Fırat Ün. Orta Doğu Araştırmaları Dergisi 1. Elazığ: 2007, 165-220.

Mu'nis, Huseyin. Me'âlimu târihi'l-Magrib ve'l-Endülüs. Kahire: Dârü'r-reşâd. 2004.

Mekkî, Ebu Talip. Kûtül-Kulûb. Kahire: Daru'r-reşad. 1961.

Mevsilî, Abdullah b. Mahmud. El-İhtiyar li Ta'lil'il-Muhtar. 2 cilt. Kahire: Daru'l-Fikr. ts.

Maşalı, Münteha. Makdisî'nin Ahsenü't-Tekâsim'i Bağlamında Fıkıh Coğrafyası. Usûl İslam Araştırmaları Dergisi 25, İstanbul: 2016. 25: 63-106.

Nübâhî, Ebû'l-Hasen b. Abdullah b. Hasen. Târîhu Kudâti'l-Endelüs. Beyrut: 1983.

Özdemir, Mehmet. Endülüs Müslümanlar1-I. Ankara: TDV Yay. 2010.

Özel, Ahmet. İmam Ebu Hanife ve Hanefi Mezhebi. Ankara: DİB yay. 2015.

Öztoprak, Mustafa. Endülüs Hadisçiliğinde Kadıların Yeri. Şırnak Üniveristesi-İlahiyat Fak. Dergisi 4/7. Şırnak: 2013.

Selkînî, İbrahim. El-Müyesser fì usuli'l-F1kh. Dubai: Daru'l-irşad. 1990.

Songur, Haluk. Human Rights And Islam: An Attempt To Compare The Farewell Address Of The Prophet and The Magna Carta. SDÜ. İlahiyat Fak. Dergisi 19. Isparta: 2007.

Şakiroğlu, Mahmut H. "Sicilya" Türkiye Diyanet Vakfı İslam Ansiklopedisi. Ankara: TDV Yay, 2009.

Şimşek, Murat. Mezhepleşme Sürecinde Hanefilik. Konya: y.y. 2014.

Şirbini, Mahmut. El-Kada fi'l-İslam. 2. Baskı. Mısır: y.y. 1999.

Tolmacheva, Marina A. "Makdisî", Türkiye Diyanet Vakfı İslam Ansiklopedisi, Ankara: TDV Yay., 2003.

Temimî, Ebu'l-Arab Muhammed b. Ahmed (333/945). Kitabu Tabakâtu 'ulemâ-i İfrîkıyye. Beyrut:Dâru'1-Kitâbi'1-Lubnânî. ts.

Temîmî, Ebu'l-Arab Muhammed b. Ahmed (333/945). Tabakâtü 'ulemâi İfrîkıyye ve Tûnis. nşr. Ali eş-Şâbbî-N. Hasan el-Yâfî. Tunus: Daru'l-Kütübü'l-Lübnanî.1985.

Uzzârî, Ebu'l-Abbas Ahmed b. Muhammed (h.712). el-Beyânu'l-mağrib fi ihtisâri ahbâri'lEndelüs ve'l-Mağrib. 4 cilt. Tunus: Daru'l-garbi'l-islamî. 2013.

Zebidi, Muhibbuddin Ebi Feyz es-Seyyid Muhammed Murtaze el-Huseyni. Tâcü'l-arûs min cevâhiri'l-kâmûs. Kuveyt: Matbaatü Hukumetu'l-Kuveyt. 1987. 40 cilt. 1987. 
Zehebî, Hafız Ebû Abdillâh Şemsüddîn Muhammed b. Ahmed b. Osmân (748/1348). El-İber fi Haber min Giber. 4 cilt. Beyrut: Darü'1-Kütübü'1-Ilmiyye. ts.

Zehrânî, Muhammed b. Sa'îd. el-Hayâtü'l-İlmiyye fî Sikıliyyeti'l-İslâmiyye. Mekke: İhyâu'ttürasi'l-Arabî. 1993. 


\title{
Hanafism in Sicilia
}

\begin{abstract}
Within the sects, that have survived until today and the most common sect from the East to the West is the Hanafi sect which has the highest share in the Muslim geography. The founding personality of the sect in the formation of the concept of sect with the views and thoughts of the Imam-l Azam in the popularity of the Hanafi school, to interpret the legal interpretations of the teachers according to the conditions of the day and at the same time the invention of the method (istihsan) is important. This can be added to the fact that Hanafism is accepted as an official sect, that Abu Hanifa's students compile the jurisprudence of the sect, that there is a series of students who will convey sectarian views from generation to generation and the need to make a law.

The teacher and the Qadi practice sent by the Prophet to the new Muslim communities were continued in the following caliphs. The first conquests of Muslims in the Eastern lands and the Islamic moral values and literary teachings of these lands were taken by Muslims and the fiqh and law surrounding the daily lives of Muslims were also taken. This practice was preserved in Egypt, which is the first step of Islam in the West, and in North Africa where it was spread. The Practices of sending of the teachers and qadi's to Egypt in the period of Khalifa Osman and then which were continued during the period of Omar b. Abdulaziz, it was the occasion of this country to comprise of the first Muslim and then the individual sects based on the person around them.

In the 2nd century after emigration to Madinah, the process of formation of sects starting in cities like Kûfe, Damascus and Medina influenced the geography in the West. Many teachers who were educated in the madrasas in the East transferred this education to the newly conquered lands in the West so that the concept of sectarianism started in the East and West at the same time. During this period, the views of many interpreters of Islamic law (muctehid imams), including Abu Hanifa and his students, the founder of Hanafi school, began to enter this geography through students.

Since the Abbasids, who came into after Umayyads in 750, had an active role in the state administration as the official sect, the Hanafi sect reaching the lands of the Maveraünnehir in the East, firstly in the East, was first spread to Northwest Africa and then to the lands of Sicily and Andalusia.

In this article, the short period of the Hanafi sect's transition to the Western lands, the contributions of the judges in the dissemination of this sect, first of from these judges the influence of the conqueror of Sicily Esed b. Furat and the contributions of later judges, the reasons of finding fans on the island the reasons for the supporters and the loss of their influence, will be followed and the history of the course of the sect in Sicily will be explored.
\end{abstract}

Key Words: Islamic Law, Hanafism, Sicilia, Sect, region of Islamic Law(fiqh) 